\title{
FISCAL MANAGEMENT IN MYANMAR
}

Zaw Oo, Cindy Joelene, Paul Minoletti, Phoo Pwint Phyu, Kyi Pyar Chit Saw, Ngu Wah Win, lan Porter, Mari Oye, and Andrea Smurra

NO. 434

June 2015
ADB ECONOMICS WORKING PAPER SERIES 


\section{ADB Economics Working Paper Series}

\section{Fiscal Management in Myanmar}

Zaw Oo, Cindy Joelene, Paul Minoletti, Phoo Pwint Phyu, Kyi Pyar Chit Saw, Ngu Wah Win, Ian Porter, Mari Oye, and Andrea Smurra

No. 434 | June 2015
The paper was prepared by researchers from the Myanmar Development Resource Institute-Centre for Economic and Social Development (MDRI-CESD), and the International Growth Centre, Myanmar (IGC).

\section{MDRI-CESD}

Zaw Oo, Executive Director (zaw.oo@mdri-cesd.org) Cindy Joelene, Research Associate (cindy.cesd@gmail.com)

Paul Minoletti, Research Coordinator (paul.minoletti77@hotmail.co.uk) Phoo Pwint Phyu, Research Associate (phoopwintphyu.cesd@gmail.com) Kyi Pyar Chit Saw, Research Associate

(kyipyarchitsaw@gmail.com)

Ngu Wah Win, Research Associate (nguwah.cesd@gmail.com)

IGC

Ian Porter, Country Director, but was an ADB consultant at the time of writing (iancporter@gmail.com)

Mari Oye, Myanmar Country Economist (myanmar@theigc.org)

Andrea Smurra, Myanmar Country Economist

(andrea.smurra@theigc.org) 
Asian Development Bank

6 ADB Avenue, Mandaluyong City

1550 Metro Manila, Philippines

www.adb.org

(C) 2015 by Asian Development Bank

June 2015

ISSN 2313-6537 (Print), 2313-6545 (e-ISSN)

Publication Stock No. WPS157441-2

The views expressed in this paper are those of the authors and do not necessarily reflect the views and policies of the Asian Development Bank (ADB) or its Board of Governors or the governments they represent.

ADB does not guarantee the accuracy of the data included in this publication and accepts no responsibility for any consequence of their use.

By making any designation of or reference to a particular territory or geographic area, or by using the term "country" in this document, $A D B$ does not intend to make any judgments as to the legal or other status of any territory or area.

Note: In this publication, "\$” refers to US dollars.

The ADB Economics Working Paper Series is a forum for stimulating discussion and eliciting feedback on ongoing and recently completed research and policy studies undertaken by the Asian Development Bank (ADB) staff, consultants, or resource persons. The series deals with key economic and development problems, particularly those facing the Asia and Pacific region; as well as conceptual, analytical, or methodological issues relating to project/program economic analysis, and statistical data and measurement. The series aims to enhance the knowledge on Asia's development and policy challenges; strengthen analytical rigor and quality of ADB's country partnership strategies, and its subregional and country operations; and improve the quality and availability of statistical data and development indicators for monitoring development effectiveness.

The ADB Economics Working Paper Series is a quick-disseminating, informal publication whose titles could subsequently be revised for publication as articles in professional journals or chapters in books. The series is maintained by the Economic Research and Regional Cooperation Department. 


\section{CONTENTS}

TABLES, FIGURES, AND BOXES iv

ABSTRACT

$\begin{array}{ll}\text { I. INTRODUCTION } & 1\end{array}$

A. Public Finances Prior to 2011

B. Recent Developments 1

C. The Government of Myanmar's Fiscal Management Objectives 3

D. Outline 3

II. STRATEGIC RESOURCE ALLOCATION 3

A. Increasing the Level and Adjusting the Sectoral Allocation of Public Expenditures 4

B. Balancing Capital and Recurrent Expenditures 6

C. Balancing Public and Private Expenditures 7

D. Enhancing the Efficiency and Effectiveness of Public Expenditures 10

E. Strengthening the Planning and Budgeting System 10

III. RESOURCEMOBILIZATION 12

A. Government Revenues from Natural Resources $\quad 12$

B. State-Owned Enterprises $\quad 15$

C. Tax System 16

D. Foreign Aid and Borrowing 20

IV. FISCAL DECENTRALIZATION 21

A. $\quad$ Links between Political, Administrative, and Fiscal Decentralization 22

B. Pillars of Fiscal Decentralization $\quad 23$

C. $\quad$ Fiscal Decentralization and Sharing Natural Resource Wealth 27

$\begin{array}{ll}\text { V. MACRO FISCAL LINKAGES } & 28\end{array}$

A. Fiscal Policy for Stability, Growth, and Poverty Reduction 28

B. Management of Fiscal Risks 29

C. Budget Deficit Financing and Debt Sustainability 30

D. Macroeconomic Management $\quad 31$

VI. TRANSPARENCY, ACCOUNTABILITY, AND PUBLIC FINANCIAL
MANAGEMENT REFORM

A. Overview of Public Financial Management Reform Issues and Strategy 32

B. Transparency and Accountability 33

C. Reforms of Systems, Procedures, and Rules $\quad 35$

D. Institutional Restructuring $\quad 36$

E. Implementation and Capacity Building 38

$\begin{array}{ll}\text { REFERENCES } & 39\end{array}$ 


\section{TABLES, FIGURES, AND BOXES}

\section{TABLES}

$1 \quad$ General Government Expenditures

2 Cross-Country Comparison of Public Expenditures by Sector, 2011

3 Cross-Country Comparison of Ratios of Government Wages to Government Expenditures, Government Revenues, and Gross Domestic Product $\quad 7$

4 Health Expenditures in Selected ASEAN Countries, 2011

5 Revenues of the Nonfinancial Public Sector 12

6 Natural Resource Extraction 13

7 Tax Revenues, Selected ASEAN Countries 17

$8 \quad$ Government Tax Revenues 18

9 Net Official Development Assistance Received per Capita 20

10 State and Region Budget Units and Constitutional Assignments 24

\section{FIGURES}

$1 \quad$ Public Expenditure Allocation by Sector 4

2 Cross-Country Comparison of Recurrent Expenditure, 2008-2011 6

3 Conceptual Framework of Efficiency and Effectiveness 10

4 Types of Central Government Transfers 25

\section{BOXES}

$1 \quad$ Public Sector Employment and Wages, International Perspective 8

2 The Potential of Public-Private Partnerships, International Experience 9

3 Improving Capital and Current Budget Planning and Implementation 11

$4 \quad$ Resource Curse 14

$5 \quad$ Natural Resource Management, International Experience 15

$6 \quad$ State Asset Reform Options 16

7 Donor Coordination, Country Experience $\quad 21$

$8 \quad$ Principles of Transfer Design 26

9 Fiscal Decentralization, Lessons of Country Experience $\quad 27$

10 Constructing Wealth-Sharing Arrangements 28

11 Fiscal Risk Management, Review of Country Experiences 30

12 Operational Roles of the Treasury and the Central Bank 32

13 EITI: Lessons of International Experience $\quad 34$

14 Implementation of Public Financial Management Reforms in Africa 38 


\begin{abstract}
Past governments in Myanmar presided over a system generally characterized by weak fiscal management, but this has recently changed with the present government restoring a measure of fiscal discipline, reorienting fiscal priorities, and establishing a clear set of fiscal objectives in the Framework for Economic and Social Reforms (FESR), which was finalized in June 2013. The Government of Myanmar now has to prioritize how best to implement these fiscal objectives while strengthening longrun fiscal discipline. This paper provides a broad range of recommendations on how this can be achieved, using analysis of Myanmar's present and past fiscal situation alongside insights provided by the experience of other countries.
\end{abstract}

Keywords: budget and expenditure framework, fiscal policy, Myanmar, public financial management, resource mobilization

JEL Classification: E62, H61, H72, O23 



\section{INTRODUCTION}

\section{A. Public Finances Prior to 2011}

Prior to 2011, spending priorities were heavily distorted, which had a large influence on Myanmar's low level of economic and human development. For the period 2004-2009 government spending on the military was consistently higher than spending on health and education combined, with Myanmar being the only country in Southeast Asia where this was the case (Turnell 2011). The Government of Myanmar consistently ran budget deficits, with the vast majority of these deficits financed by the government-controlled central bank printing money, with the inevitable result of high inflation. The highly overvalued official exchange rate negatively impacted the economy in a variety of ways, and from a fiscal perspective meant that the true value of the income of state economic enterprises (SEEs) did not appear in government accounts, with this problem being particularly acute for SEEs operating in the gas and oil industries.

The legally defined tax regime was extremely complicated and this, together with the low capacity of tax administration, resulted in a system where the tax that individuals and businesses actually paid was highly arbitrary, albeit often following certain norms within a given geographical area or sector. The complicated nature of tax regulations and low capacity for enforcement created many perverse incentives and encouraged rent-seeking. Although the fiscal system was highly centralized in theory, and in many aspects continued to be in practice, the central government was not the only actor that could levy taxes or "charges" from citizens and businesses. These taxes or charges could also be levied by: (i) Township Peace and Development Councils, (ii) Village Peace and Development Councils, (iii) state and nonstate military organizations, and (iv) government organized "nongovernmental organizations" (GONGOs) (Turnell 2011). A low level of transparency and rules-based procedures was a feature of how revenue was collected and how it was allocated for spending at all levels of the fiscal system.

\section{B. Recent Developments}

In April 2012, the government replaced the overvalued fixed exchange rate with a managed float at a realistic rate. This has resulted in higher revenues from SEEs appearing in government accounts. Since 2011 many loss-making SEEs have been privatized, with further privatizations, corporatizations and public-private partnerships planned. These privatizations have been focused on loss-making entities and so can be expected to have a positive impact on the government's balance sheet. The government has been working to reform tax policy, which will involve reforming the tax on special consumption goods and expanding taxation of services. In the long run, the government intends to introduce a full value-added tax (VAT) system. All of these changes should increase government revenues. However, several recent pieces of legislation threaten to have the opposite effect, notably the Special Economic Zone Law (January 2011), Foreign Investment Law (November 2012), and Citizens Investment Law (July 2013). These pieces of legislation provide a range of tax breaks and holidays for businesses, thereby reducing the amount of revenue the government will be able to collect.

Moves have been made to create an independent central bank and a new Central Bank Law was introduced in July 2013, granting far greater autonomy to this institution than was previously the case. The Central Bank of Myanmar (CBM) and the government have committed to gradually phase out the monetization of budget deficits. If this is achieved, it can be expected to deliver significant macroeconomic benefits. 
With so many changes occurring in both the political and economic spheres, financial risk is high; and the World Bank has identified weak internal control and central oversight of spending and revenue collection as potential barriers to effectively dealing with this risk (World Bank 2013). And while the increased revenues that will arise from the move to a realistic exchange rate are certainly welcome, the increased contribution of natural resource revenues to overall revenues will inevitably increase the volatility of overall revenues.

The last couple of years have seen big increases in spending on health and education, and large rises in civil service pay and pensions. However, military spending has also continued to increase over this period and accounted for $27 \%$ of government spending for FY2013, i.e., still higher than spending on health and education combined (Section II.A). Current expenditure has increased relative to capital expenditure, but Myanmar's spending is still more tilted toward capital expenditure than that of other countries in the Association of Southeast Asian Nations (ASEAN).

The 2008 Constitution stipulated that certain fiscal responsibilities should be decentralized to the governments of states and regions. In a speech made in August 2013, President Thein Sein outlined additional decentralization of certain fiscal operation (The New Light of Myanmar 2013); and further fiscal decentralization is possible within the next few years. In the long run, these changes should make spending more efficient and responsive to public needs and desires, but the low capacity that subnational governments currently have for carrying out fiscal responsibilities mean that considerable efficiency gains are unlikely to arise from this change in the short run.

The government has committed to implementing the Extractive Industries Transparency Initiative (EITI), which will help boost fiscal transparency. The Budget Law was made public for the first time in FY2012, also representing a significant step toward greater transparency of fiscal matters. However, although important steps have been made to increase transparency, much remains to be done. Many government and other public sector entities do not fully report their financial operations, and "Other Accounts" are widely used (there are over 13,400 in total). 'The amount of key fiscal information made available to the public also remains lower than in most other countries, limiting the input citizens and other nongovernmental actors can have on fiscal management issues.

The Internal Revenue Department has adopted a strategic reform plan that includes the establishment of a Large Taxpayer Office (LTO), which became operational in April 2014. The LTO has introduced taxpayer self-assessment and issued unique taxpayer identification numbers, and will be used as a model for establishing Medium Taxpayer Offices, and the reform of small taxpayer compliance methods. These changes should help the government to improve its revenue collection. Technical assistance for these changes is being sought from international organizations, as is the case with a variety of other changes the government seeks to make to its fiscal administration (IMF 2013). Following the political liberalization of the last few years, the international community has abolished or suspended most sanctions, relations with major international financial institutions (IFIs) have been normalized, and more than half of Myanmar's external debt has been written off. These changes can be expected to improve Myanmar's future fiscal performance.

See Section VI.C for a detailed discussion of this issue. Most of the accounts belong to state-owned enterprises, but some belong to government ministries. 


\section{The Government of Myanmar's Fiscal Management Objectives}

In the Framework for Economic and Social Reforms (FESR), the government outlines its plans for health and education to account for an increasing proportion of government spending, while the share spent on the military will decline. The government also recognizes the need to reduce reliance on resource revenues and is therefore prioritizing the reform of tax policy and tax administration as well as a gradual shift away from direct to indirect taxation. The Ministry of Finance and Revenue (MoFR) has set a target of achieving a 10\% tax-to-gross domestic product (GDP) ratio (i.e., more than double the current ratio) by 2018. The MoFR also recognizes the need to broaden what is currently a very narrow tax base (IMF 2013).

Monetary policy still has a limited role in Myanmar, so in the short- to medium-term, fiscal policy will remain the main instrument for managing macroeconomic stability and growth. However, fiscal policy also needs to be used to address the country's large and pressing human development needs. In order to deliver optimal fiscal reform, the MoFR has established a working group to develop public financial management (PFM) reform strategies and help to coordinate international donorsboth financial and technical cooperation is being sought from the international community.

\section{Outline}

Section II examines the strategic resource allocation, covering: the level and sectoral allocation of public expenditures, balancing capital and recurrent expenditures, balancing public and private expenditures, enhancing the efficiency and effectiveness of public expenditures, and improving the planning and budgeting system. Section III covers various aspects related to resource mobilization, namely: revenues from natural resources, SEE resources, taxes, and foreign aid and borrowing. Section IV discusses the recent move to fiscal decentralization, paying particular attention to: the links between political, administrative and fiscal decentralization; progress on the four pillars of fiscal decentralization; and the links between fiscal decentralization and sharing natural resource wealth. Section $V$ considers the importance of macro fiscal linkages, and analyses: the links between fiscal policy and stability, growth, and poverty reduction; management of fiscal risks; budget deficit financing and debt sustainability; and macroeconomic management. Section VI concludes the chapter with an assessment of accountability, transparency, system reform and institution building, focusing on: the Public Expenditure and Financial Accountability (PEFA) assessment, EITI, further PFM reforms, and institutional reform and capacity building.

The following sections endeavor to contribute to the implementation of government objectives by providing an overview of the recent past and current situation in Myanmar, highlighting the linkages between fiscal management issues and other macroeconomic and sectoral issues, and drawing on the experience of other relevant countries to make concrete and practical suggestions for policy changes and system reform.

\section{STRATEGIC RESOURCE ALLOCATION}

In the FESR, the government makes it clear that in order to support both growth and poverty reduction, it needs to increase public expenditures on the social sectors and infrastructure as well as provide appropriate support for other critical sectors, including agriculture and rural development, and industry. International experience confirms the importance of such an approach. Indeed, analysis of cross-country differences in per capita incomes and growth rates clearly shows that they are 
determined in part, at least, by investment in infrastructure and human capital. Public spending in favor of human resource development and investment in physical capital leads to relatively high GDP growth, whereas spending on military capital is negatively related to GDP growth (Baffes and Shah 1993). It is also clear that it is not only the quantity but also the quality of investments in infrastructure (as well as the social sectors) that is positively linked to long-run economic growth and more equitable income distribution (Calderon and Serven 2004).

This international experience provides valuable support for the government's overall strategy. But to make sure that public expenditures have the desired impact, it will be important to carefully review the level and sectoral allocation of those expenditures, the balance between capital and recurrent expenditures, the relationship between public and private expenditures, and how the overall efficiency and effectiveness of public expenditures can be increased; and this, in turn, will require significant improvements in planning and budgeting systems.

\section{A. Increasing the Level and Adjusting the Sectoral Allocation of Public Expenditures}

Consistent with the priorities laid out in the FESR, the government has increased expenditures on education and health significantly during FY2011 and FY2014 (Figure 1). However, expenditures on defense have also increased, while expenditures on agriculture (another key priority of the government) have remained almost constant. Moreover, it will take many years to address the huge backlog of investment needs in priority sectors. In education, for example, it has been proposed that public funding should be raised from 1\% of GDP in recent years to 3\% of GDP by 2015, and then maintained at least at that level for the next decade; and in infrastructure, it has been estimated that Myanmar faces an investment gap of anywhere between $\$ 2.3$ billion and $\$ 4.7$ billion per year (depending on the overall growth rates being targeted).

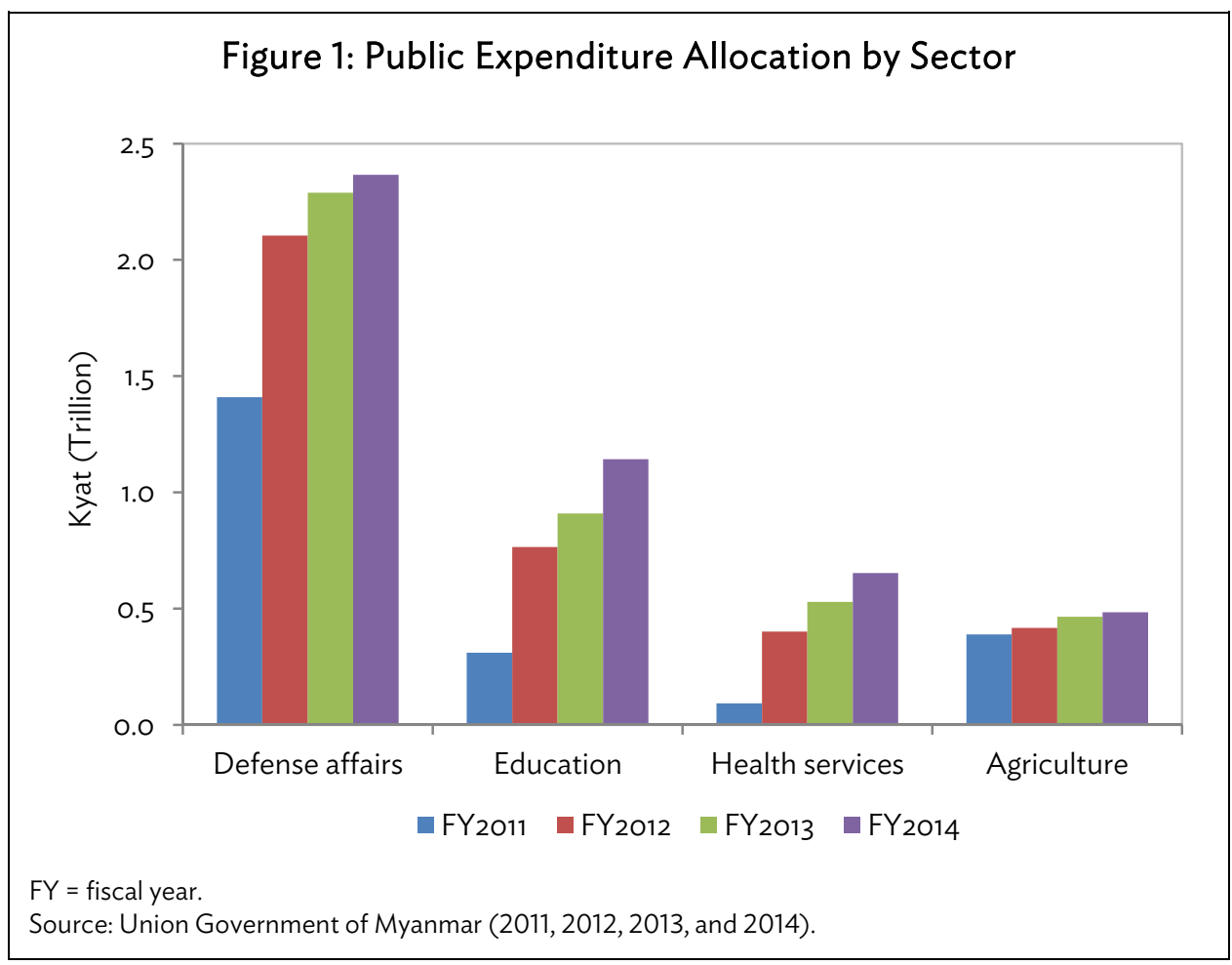


Going forward, the government should be able to further increase expenditures in priority areas in the context of an overall growth in the level of real public expenditures. In this regard, a comparison of Myanmar with neighboring countries shows that the ratio of public expenditures to GDP has been increasing but is still below the ratios prevailing in other countries (Table 1). But, whether and by how much real public expenditure can increase will depend on the possibilities for revenue expansion (Section III). It is of vital importance for macroeconomic stability that the government maintains its commitment to keeping the budget deficit at no more than $5 \%$ of GDP. ${ }^{2}$

\section{Table 1: General Government Expenditures} (\% of GDP)

\begin{tabular}{|l|c|c|c|c|c|}
\hline & 2008 & 2009 & 2010 & 2011 & 2012 \\
\hline Myanmar & 8 & 9 & 10 & 10 & 17 \\
\hline Cambodia & 16 & 20 & 20 & 20 & 19 \\
\hline Indonesia & 21 & 18 & 18 & 18 & 19 \\
\hline Lao PDR & 19 & 23 & 23 & 21 & 22 \\
\hline Malaysia & 28 & 32 & 28 & 29 & 30 \\
\hline Philippines & 19 & 20 & 19 & 18 & 19 \\
\hline Thailand & 21 & 24 & 23 & 23 & 24 \\
\hline
\end{tabular}

GDP = gross domestic product, Lao PDR = Lao People's Democratic Republic.

Note: The large increase in general government expenditures as a percent of GDP between 2011 and 2012 in Myanmar is mainly a result of the exchange rate reform and the considerable depreciation of the kyat, which in turn significantly increased the value of government expenditures with high import content.

Sources: World Bank 2012; IMF (2012, 2013, and 2014).

Moreover, a comparison of Myanmar with other countries suggests that there is still huge potential for raising the level of expenditures in priority areas by shifting the sectoral allocation of public expenditures (Table 2). In the education sector, for example, expenditures were around 3\% to $4 \%$ of total public expenditures from 2008-2009 to 2011-2012 and currently account for $10 \%$ to $12 \%$ of total public expenditures. But neighboring countries spend $15 \%-25 \%$ of total government spending on education. Similarly, the health sector accounts for a much smaller share of public expenditures in Myanmar than in neighboring countries. By contrast, defense expenditures account for a much larger share of government expenditures than in most neighboring countries. Accordingly, the government can look to furthering its development priorities through a reallocation of public spending away from the unproductive sectors and security, and toward the social sectors and other priorities such as agriculture.

2 See Section $\vee$ for further discussions on the level of the budget deficit. 
Table 2: Cross-Country Comparison of Public Expenditures by Sector, 2011 (\% of total public expenditures)

\begin{tabular}{|l|c|c|c|c|c|}
\hline & Cambodia & Malaysia & Myanmar $^{\text {a }}$ & Philippines $^{\text {Thailand }}$ \\
\hline Agriculture & 1.50 & 2.58 & 4.58 & 5.49 & 1.91 \\
\hline Education & 13.73 & 21.60 & 3.66 & 13.90 & 21.24 \\
\hline Health & 12.17 & 7.48 & 1.09 & 2.46 & 10.46 \\
\hline Infrastructure $^{\mathrm{b}}$ & $1.12^{\mathrm{c}}$ & 10.41 & 30.96 & 18.64 & 1.82 \\
\hline Defense & 22.70 & 11.14 & 16.64 & 5.23 & 14.42 \\
\hline Other $^{d}$ & 48.78 & 46.79 & 43.07 & 54.28 & 50.15 \\
\hline Total & 100.00 & 100.00 & 100.00 & 100.00 & 100.00 \\
\hline
\end{tabular}

a In FY2014, education and health expenditure of Myanmar has increased to $11.08 \%$ and $6.3 \%$ of total public expenditure, respectively (Union Government of Myanmar 2014).

b Infrastructure includes transport, communication, electricity, gas, and water.

c Cambodia data exclude electricity, gas, and water.

d Others include industry, housing committee, social security and welfare, general public service, economic services, and others.

Sources: ADB (2013a and 2013b), Union Government of Myanmar (2011 and 2012).

\section{B. Balancing Capital and Recurrent Expenditures}

Public expenditures can be categorized into capital and recurrent expenditures. Capital expenditures include expenses for building roads, bridges, universities, hospitals, and clinics, etc.; whereas, recurrent expenditures include wages and salaries, maintenance and repairs, interest payments, etc. As can be seen in Figure 2, Myanmar's ratio of recurrent expenditures to GDP has been lower than that of neighbors, suggesting that further real growth in recurrent expenditures will be both feasible and desirable.

Figure 2: Cross-Country Comparison of Recurrent Expenditure, 2008-2011

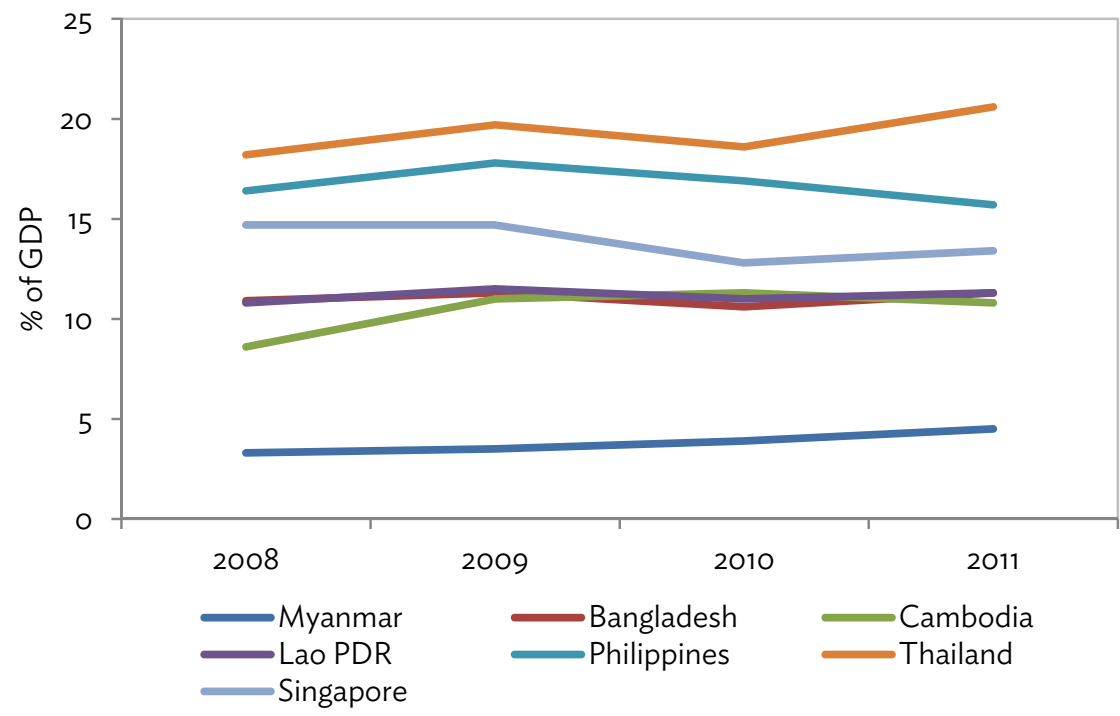

GDP = gross domestic product, Lao PDR = Lao People's Democratic Republic.

Sources: IMF 2013; World Bank, World Development Indicators (accessed December 2014). 
One critical component of recurrent expenditures is the resources needed to maintain infrastructure and run services. In this regard, infrastructure maintenance should receive high priority because the returns to adequately maintaining existing infrastructure will almost certainly exceed the returns to building new infrastructure. The other critical components of recurrent expenditures are wages and salaries, which have accounted for $20 \%$ to $30 \%$ of recurrent expenditures during 20072013 and from 10\% to 12\% of total government expenditure (Table 3). It is estimated that general government employment (including employment in the military) totals about 2 million people, or about $3.8 \%$ of the population. The average wage or salary of a government employee is about 100,000 kyat per month and the wage compression ratio (measured by dividing the ninth decile to the first decile of public administration wages) is around 5. The government has increased wages substantially over the past couple of years and, with significant additional hiring planned, the wage bill is expected to increase further. The wage bill as a proportion of expenditures and revenues is still low by regional standards and public sector salaries are only beginning to approach levels in neighboring low-income countries. But international experience (Box 1) would strongly suggest that further major adjustments to wages and salaries should be undertaken as part of a medium-term reform program aimed at enhancing the overall effectiveness and efficiency of public sector employment and remuneration. It is noteworthy that while the ratio of government wages to GDP per capita in Myanmar is still relatively low compared with other low-income countries (1.3 compared with 1.9), total government employment ${ }^{3}$ as a percent of the total population is high relative to other low-income countries (3.8\% compared with 1.1\%), in part at least because of the large size of the military.

\section{Table 3: Cross-Country Comparison of Ratios of Government Wages to Government Expenditures, Government Revenues, and Gross Domestic Product}

\begin{tabular}{|l|c|c|}
\hline & Wages/Expenditures & Wages/GDP \\
\hline Myanmar & 10.69 & 1.16 \\
\hline Thailand & 40.99 & 6.85 \\
\hline Singapore & 30.21 & 4.64 \\
\hline
\end{tabular}

GDP = gross domestic product.

Note: Ratios are averages over the period 2007-2014

Source: World Bank, World Development Indicators (accessed December 2014).

\section{Balancing Public and Private Expenditures}

In determining the appropriate level of expenditures, particularly with respect to the social sectors and infrastructure, it will be important that the government takes account of the potential for private expenditures to complement or supplement public expenditures. There are two dimensions to this issue that need to be considered, the first is the balance between public and private provision of public services, and the second are the opportunities for public-private partnerships in service provision.

3 Total government employment includes military employees. 


\section{Box 1: Public Sector Employment and Wages, International Perspective}

Employment. Government and total public sector employment as a percentage of the population tend to rise with a country's level of income. According to the ILO statistics, general government employment (i.e., including both central and local governments and employment in the armed forces) ranges from $1.1 \%$ of the population in low-income countries to $5.3 \%$ in middle-income countries, and $7.9 \%$ in high-income countries; and total public sector employment (i.e., including state-owned enterprises) ranges from $4 \%$ of the population in low-income countries to $6.8 \%$ in middle-income countries, and $9.2 \%$ in high-income countries. General government employment in countries in East Asia is about $4 \%$ of the population, and in South Asia, about 3\%. But these averages do mask significant differences across countries within different income and regional groupings depending, among other things, on the overall role expected of the public sector.

Remuneration. Average public administration wages are generally higher than per capita GDP, with the ratio ranging from 1.9 in low-income countries to 1.4 in middle-income countries, and 1.2 in high-income countries. Average public administration wages are also consistently above wages in the manufacturing sector across all income and regional groupings (the ratio ranges from 1.3 to 1.8) and consistently below average wages in the financial sector (the ratio ranges from 0.5 to 0.9). It should also be noted that average public administration wages may mask large variations in the overall structure of wages within public administration. Indeed even across ASEAN countries, the wage compression ratio (measured by dividing the ninth deciles to the first deciles of earnings) varies greatly, for example, from 2 in Indonesia to 6 in Cambodia, 9 in the Philippines, and 14 in Thailand.

Reform. International experience with respect to enhancing the effectiveness and efficiency of public sector employment and remuneration systems suggests the following: first, while there are some short-term options to address periods of severe fiscal pressure, rationalizing government employment and wages is more properly viewed as an issue of medium and longer term reform; second, a review of employment may need to go hand-in-hand with broader expenditure reviews that examine the role of government, the cost effectiveness of different policy options, potential for outsourcing of noncore functions, areas of duplication and overlap etc., and third, increases in wage levels should ideally be linked with broader reforms of the pay and incentives system, including the potential for linking pay increases with performance, rationalization of allowances and other benefits, increasing internal mobility, training and other career development opportunities, and enhancing accountability.

ASEAN = Association of Southeast Asian Nations, GDP = gross domestic product, ILO = International Labour Organization. Sources: Clements et al. 2010; World Bank 2011; and World Bank, World Development Indicators (accessed July 2014).

With respect to the balance between public and private expenditures, international experience and even experience within ASEAN varies greatly. In the health sector, for example (Table 4), health expenditures as a percentage of GDP vary significantly from a low of $2 \%$ in Myanmar to $7 \%$ in Viet $\mathrm{Nam}$. In addition, the share of total health expenditures accounted for by the public sector varies even more widely, from 13\% in Myanmar to $76 \%$ in Thailand. It is clear that Myanmar needs to work hard to significantly increase total expenditures relative to GDP and the share of those expenditures accounted for by the public sector. But the appropriate ratio of private expenditures on health relative to GDP is a more open question and will need careful consideration as part of the development of the government's overall sector strategy.

There is much discussion in Myanmar about public-private partnerships (PPP); and as part of the reform of SEEs, some enterprises have already been transformed into PPPs. International experience, however, suggests that the government should proceed cautiously in this area and give careful consideration to the sectors where such partnerships may be most effective, the nature of the partnerships that would be most advantageous, and the regulatory framework that needs to be in place to maximize the probability of success (Box 2). International experience also strongly suggests that even with a strong emphasis on PPPs, the bulk of both infrastructure and social sector investment will remain a government responsibility. 
Table 4: Health Expenditures in Selected ASEAN Countries, 2011

\begin{tabular}{|l|c|c|c|c|c|c|c|c|}
\hline & Cambodia & Indonesia & Lao PDR & Malaysia & Myanmar & Philippines & Thailand & Viet Nam \\
\hline $\begin{array}{l}\text { Total } \\
\text { health } \\
\text { exps (\% of } \\
\text { GDP) }\end{array}$ & 5.7 & 2.7 & 2.8 & 3.6 & 2.0 & 4.1 & 4.1 & 6.8 \\
\hline $\begin{array}{l}\text { Public exps } \\
\text { on health } \\
\text { (\% of total } \\
\text { health } \\
\text { exps) }\end{array}$ & 22.4 & 34.1 & 49.3 & 45.7 & 13.0 & 33.3 & 75.5 & 40.4 \\
\hline
\end{tabular}

ASEAN = Association of Southeast Asian Nations, exps $=$ expenditures, GDP = gross domestic product, Lao PDR $=$ Lao People's Democratic Republic.

Source: World Bank, World Development Indicators (accessed July 2014).

\section{Box 2: The Potential of Public-Private Partnerships, International Experience}

Sectoral Coverage. Public-private partnerships (PPPs) can be used in a range of sectors, including the economic and the social sectors as well as sectors where there are varying extents of competition. But they are more widely used in the economic sectors, especially infrastructure. Moreover, wherever they are used, they should be seen as fostering and supplementing but not substituting for the role and obligations of the state in ensuring populations have access to vital services such as transport and education.

Spectrum of PPP Models. There is a broad range of PPP options. In the case of infrastructure, the options range from design-build to outright privatization, where the government transfers all responsibilities, risks, and rewards for service delivery to the private sector. Within this spectrum, PPP options can be categorized based on the extent of public and private sector involvement and the degree of risk allocation-with an operation and maintenance PPP, for example, involving less private sector involvement and less private sector risk than a design-build-finance-maintain-operate PPP.

Preconditions for PPPs. While there are varying perspectives on the notion of preconditions for implementing PPPs, most experience would suggest that a clear and transparent legal and regulatory framework is essential to prevent abuses, including corruption, ensure that social and environmental issues are properly addressed, enhance the effectiveness and efficiency of PPPs, and ensure an appropriate balance of risks and rewards between the public and private sectors. In assessing the desirability and feasibility of a PPP, it is especially important that the level of public risk, including from the guarantees associated with PPP projects, is well-understood and appropriately reflected in the budget.

Potential. It is also important to manage expectations regarding what can be expected from private participation in infrastructure and other sectors, with respect to the size of the private sector's contribution and the time required for processing PPP operations. While the private sector can significantly contribute to public services provision, international experience suggests that the bulk of infrastructure and social sector investment will remain a government responsibility. For example, in the United Kingdom, Spain, and the Republic of Korea (all countries where PPPs have been active for at least a decade), PPP projects account for no more than $10 \%-20 \%$ of public sector investment. Also, and in light of the complexity of designing PPPs, they require a lead time that can be longer than those needed under public procurement. 


\section{Enhancing the Efficiency and Effectiveness of Public Expenditures}

Careful allocation of public expenditures will increase the likelihood that the government can achieve its sectoral goals and its broader economic and social objectives; but also crucial will be the efficiency with which public expenditure resources are used. This in turn will be determined in large measure by the quality of the governance structures and institutions responsible for the planning, implementation, and monitoring of specific programs.

The conceptual framework for addressing issues concerning the efficiency and effectiveness of public expenditures is clear (Figure 3) and much work has been done in recent years to examine such issues in both developed and developing countries. In the health sector, for example, much work has been done around the overall issue of health system performance and how inputs into the health sector (as measured by health expenditures) translate into outputs in terms of the improved health of the population. In this regard, one 2001 study of health system performance concluded that Myanmar's performance was 190th among the 191 countries studied (Tandon et al. 2001).

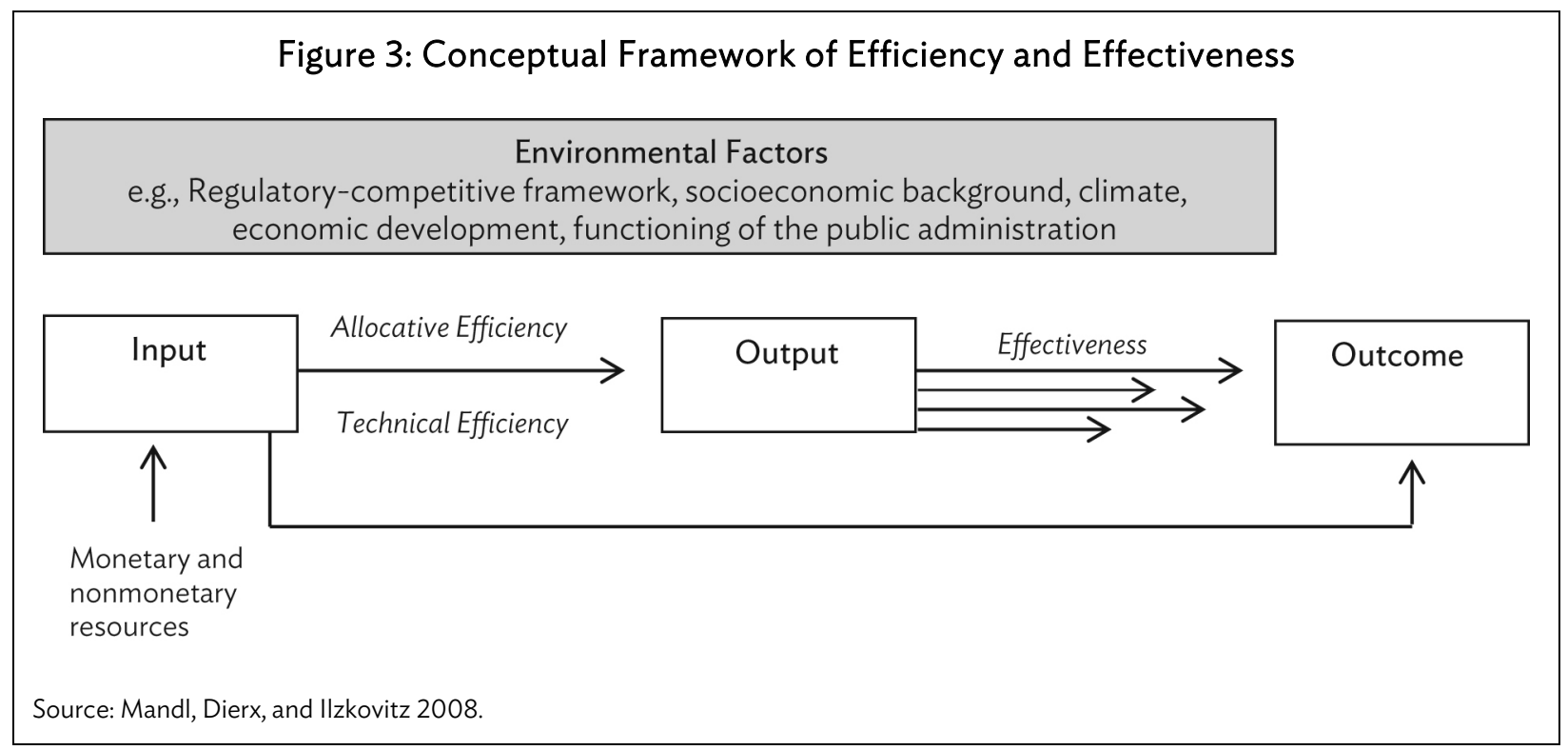

Unfortunately, relatively little work has been done in Myanmar around issues of the efficiency and effectiveness of public expenditures. So it is even more important that in the context of developing sector strategies, for many, if not all of the priority sectors, the government emphasizes the need to undertake this work. Thus, it is important that the need for carrying out such analyses is being emphasized.

\section{E. Strengthening the Planning and Budgeting System}

Meeting the government's goals will need enhancements to the planning and budgeting system. At present, the macro responsibilities for planning and budgeting are split between the Ministry of National Planning and Economic Development (MNPED) and the MoFR, and both ministries work closely with sectoral ministries in the planning and budgeting process. Such a structure is not unique to Myanmar - many other countries have separate planning and finance ministries, with planning responsible for the capital budget and finance responsible for the current budget. But it will be important to clarify roles and responsibilities and ensure the necessary coordination mechanisms are in 
place. It will also be important to strengthen coordination between national, regional, and local planning, and enhance planning and budgeting capacity at all levels in the system.

In parallel with implementing the FESR for the period 2012-2015 and preparing the 20-year National Comprehensive Development Plan (NCDP), most sectoral ministries are now in the process of developing their own sectoral strategies and programs. This is an important development that will help enhance the relevance and quality of future national plans as well as facilitating the process of determining capital budget priorities and recurrent expenditure needs. ${ }^{4}$ In this context, it will be important that sector strategies set clear objectives, determine the policies and programs that are needed to realize those objectives, consider the appropriate roles of the private and public sectors in delivering the necessary programs and outline other measures that will be needed to enhance program effectiveness, efficiency, and equity.

The development of sound sector strategies will enable better decision making on the allocation of scarce government resources between capital and current expenditures and to particular programs and projects. In addition, it will be important that the government adopts a medium-term approach in its capital public budgeting that takes into account all the resources available to the government as well as potential private sector financing (Box 3 ). All projects should be subject to costbenefit analysis and careful review, including with respect to their current expenditure requirements. Project implementation also needs to be carefully monitored, including with respect to how budget adjustments should be handled. Over the long-term, international experience also points to the importance of increasingly integrating the capital and current budgets.

\section{Box 3: Improving Capital and Current Budget Planning and Implementation}

Distinction between capital and current expenditures. Capital and current expenditures need, in some cases, to be considered separately because capital spending is closely linked to government priorities; because of the large amounts usually involved; and because it requires specific procedures for project selection and evaluation, asset procurement, and project management, etc. But capital and current expenditures also need to be considered together for efficient planning and budgeting purposes, and because investment proposals need to be appraised in terms of both capital and operating costs.

Budgeting for public investment. International experience suggests that it is important that governments adopt a medium-term approach in budgeting for public investment that takes account of the following benchmarks:

First, determining the resource envelope for expenditures-based on a medium-term approach to the budget that takes account of all revenues and expenditures (including from foreign aid) and clear policies with respect to how different types of capital expenditures should be financed (through the budget, public-private partnerships, or by public or private enterprises);

Second, efficient prioritization and selection of capital projects-with all projects being subject to cost-benefit analysis (possibly using a simplified methodology for smaller projects) and being reviewed by a public investment agency to ensure they are adequately prepared before being submitted to the cabinet for approval within the available resource envelope;

Third, efficient implementation of capital projects-under clear guidelines with regard to implementation, including how budget and other adjustments should be handled, and with the requirement that project completion reports should be prepared for all capital expenditure projects.

continued next page

4 National plans as well as government budgets require both government and parliamentary approval. 
Box 3 continued

Integration of capital and current budgets. International experience also points to the importance of increasingly integrating capital and current budgets, in recognition of the fact that the distinction between capital and current spending is often quite arbitrary or uncertain, and better resource allocation and management decisions can often be made within a single, unified (and medium-term) framework for revenues and expenditures. But this frequently takes many decades to accomplish and requires: a single (and combined) annual budget law and appropriation process; clear and unified responsibilities for budget preparation and implementation within the relevant public sector institutions; the existence of effective and widely employed investment appraisal techniques; a unified budget presentation, with supporting classification and accounting systems; and budget planning and management techniques within individual spending agencies that encourage and enable good use of financial resources.

Source: Jacobs 2009.

\section{RESOURCE MOBILIZATION}

The low level of public expenditures in Myanmar is in part a reflection of the overall low level of resource mobilization. In spite of efforts to address this issue, general government revenues, excluding net receipts of SEEs, were still below 10\% for FY2013 (Table 5) compared with levels of 17\%-23\% in other ASEAN countries. The government also relies very heavily on tax and nontax revenues from gas exports and other transfers from state economic enterprises. This system needs major reform, including a rigorous review of the mobilization of revenues from natural resources and further reform of the state enterprise sector. At the same time, the government needs to rapidly increase mobilization of resources from generally applicable through changes in tax policy and improvements in tax administration, and mobilize more resources from the international community.

\section{Table 5: Revenues of the Nonfinancial Public Sector} (\% of GDP)

\begin{tabular}{|l|c|c|c|c|c|c|c|}
\hline & FY2010 & FY2011 & FY2012 & \multicolumn{2}{|c|}{ FY2013 } & FY2014 & FY2015 \\
\hline & & (Prelim) & (Estimate) & (Budget) & (Projected) & (Projected) & (Projected) \\
\hline Total & 11.4 & 12.0 & 23.3 & 18.9 & 22.3 & 24.1 & 23.0 \\
\hline Tax revenues & 3.3 & 3.9 & 6.4 & 4.4 & 7.1 & 7.2 & 7.4 \\
\hline Transfers from SEEs & 2.0 & 2.3 & 1.6 & 1.6 & 1.5 & 2.1 & 2.1 \\
\hline SEEs net Receipts & 5.1 & 5.5 & 13.7 & 12.1 & 12.5 & 12.6 & 12.6 \\
\hline $\begin{array}{l}\text { Other nontax } \\
\text { revenues }\end{array}$ & 1.1 & 0.4 & 0.9 & 0.6 & 0.8 & 1.9 & 0.7 \\
\hline Grants & 0.0 & 0.0 & 0.1 & 0.2 & 0.3 & 0.3 & \\
\hline
\end{tabular}

$\mathrm{FY}=$ fiscal year, $\mathrm{GDP}=$ gross domestic product, $\mathrm{SEEs}=$ state economic enterprises. Sources: IMF (2012, 2013, and 2014).

\section{A. Government Revenues from Natural Resources}

Almost a century before becoming "the rice bowl of Asia," Myanmar was already a forerunner of the oil rush, with its first barrel of crude oil exported in 1853. Its geological structure, in fact, makes the country one of Asia's richest in terms of natural resources. Point-source resources are particularly abundant, including oil, gas, and a wide range of minerals, from base metals and ores to construction materials and precious gems (Table 6). In FY2013, for example, Myanmar exported \$3.3 billion worth of natural gas - $37 \%$ of total exports - and at least $\$ 1$ billion of jade (estimating the total size of the 
mining and gem trade is, however, very difficult, ${ }^{5}$ with some suggesting that the official-to-unofficial trade ratio could be close to 1:9). The most striking feature of Myanmar's extractive industry, however, is not the size but its potential. In the short-term, the soon to be commenced extraction from new gas fields will provide additional estimated export revenues of $\$ 1.65$ billion per year (Ministry of Energy 2014). In the medium- to long-term, exploration of other offshore plots and of the largely unexplored onshore resources will result in a further significant surge in revenues.

Table 6: Natural Resource Extraction

\begin{tabular}{|l|cccr|}
\hline \multirow{2}{*}{ FY } & Natural Gas & Crude Oil & \multicolumn{1}{c|}{ Jade } & \multicolumn{1}{c|}{ Gems } \\
\cline { 2 - 5 } & M.Cu.ft. & US Barrels & \multicolumn{1}{c}{ Kilograms } & \multicolumn{1}{c|}{ Carat } \\
\hline 2008 & 405,521 & $6,891,000$ & $32,924,000$ & $18,728,963$ \\
2009 & 439,615 & $6,965,000$ & $25,795,415$ & $11,315,816$ \\
2010 & 450,381 & $6,788,000$ & $46,810,120$ & $12,962,842$ \\
2011 & 455,394 & $6,623,000$ & $43,185,339$ & $13,398,763$ \\
2012 & 452,538 & $6,197,000$ & $19,080,442$ & $13,108,159$ \\
2013 & 465,120 & $6,118,000$ & $15,061,927$ & $16,310,221$ \\
\hline
\end{tabular}

$\mathrm{FY}=$ fiscal year, M.Cu.ft. = million cubic feet, $\mathrm{US}=$ United States.

Source: MNPED 2014.

Currently, a large share of government revenues is directly or indirectly related to natural resources, in particular gas. The government benefits from a broad range of revenues from oil and gas projects, including entitlements, royalties, allocations of shares, transport fees, transit fees, training and education funds, and income taxes. Precise figures on the total value of such revenues have yet to be made publicly available, but it is known that the contribution of the two major gas projects (Yadana and Yedagun) to government revenues was about $\$ 2$ billion in FY2003, had risen to $\$ 3.6$ billion in FY2010, and today is significantly larger. By comparison, in FY2012, total tax revenues were about $\$ 3.5$ billion and total revenues (including transfers from SEEs to the union government and other SEE receipts) were about $\$ 11.1$ billion. Some of the revenues from oil and gas projects are passed on to the union government and some are retained by SEEs such as the Myanmar Oil and Gas Enterprise.

Whatever the exact numbers, there is no doubt that at this stage in Myanmar's economic and social development, natural resources are a vital source of revenues to finance much-needed reforms and investments in the social sectors and infrastructure. However, effective management of these flows will be crucial in avoiding the "resource curse/Dutch disease" (Box 4) and ensuring sustained and equitable growth, fostering peace and social cohesion while avoiding macroeconomic instability (Isham et al. 2005). This will involve ensuring that the depletion of the natural resource stock is matched with an increase in the country's stock of infrastructure, human and physical capital, which in turn will boost production, employment, and innovation in other sectors of the economy. It will also be important to address the macroeconomic risks posed by the conspicuous size of the extractive industry and the overreliance on a less predictable source of revenues.

5 Mineral exports were estimated to account for $26 \%$ of total exports in FY2010. Other estimates suggest that governmentrun Myanmar Gems, Jade and Pearl Emporiums generated sales of \$3.7 billion in 2011. In 2013, \$2.6 billion worth of gems and jade were sold during Golden Jubilee Gems Expo (Pyoe Pin 2013). 


\section{Box 4: Resource Curse}

The term Resource Curse describes "the puzzling paradox suggesting that resource-rich countries tend to grow more slowly than resource-poor ones" (Brunnschweiler and Bulte 2008), e.g., Angola, Nigeria, Sudan, and Congo. International experience and economic theory outline several dynamics underlying these missed growth potentials. The most common are:

1. Volatility in commodity prices

Volatility in international commodity prices might translate into volatility of public revenues and GDP and increase the risk of macroeconomic crises.

\section{Low economic diversification}

High profitability of the extractive industry in developing countries might result in the scarce stock of capital being crowded out of other economic sectors, most notably manufacturing. The result is an economic structure characterized by little diversification and, hence, more exposed to world price fluctuations and shocks.

3. Social instability and conflict

Struggles over the ownership of natural resources have often resulted in social instability and civil war between neighboring countries or ethnic factions within a state.

\section{Dutch disease}

When world prices rise sharply or significant new reserves of natural resources are discovered, countries might be affected by a phenomenon that has come to be known as Dutch disease. A surge in the inflow of foreign currency can generate intense real appreciation of the domestic currency, depressing nonextractive export-oriented industries and generating inflation.

\section{Intertemporal allocation of spending}

Finally, both public and private sectors' spending choices might be skewed toward the present in resource-rich countries. Total size of reserves might be unknown, boosting optimism and current spending. Moreover, political dynamics might distort the intertemporal allocation of resources toward consumption, leaving too little capital or a too high stock of debt to the future government.

$\mathrm{GDP}=$ gross domestic product.

Sources: Auty 1998, Van der Ploeg and Venables 2013

Experience from other countries suggests that there are three important dimensions to an effective strategy for managing the revenues from natural resources. First is increased transparency and accountability for revenue flows from extractive industries. In this regard, the intention of the government and the private sector to commit to the EITI will be important in allowing better contracts to be designed, ensuring fair fiscal treatment of profits, and fostering inclusiveness through improved accountability. Second is the importance of carefully considering the macroeconomic and fiscal implications of different strategies for investing and saving the revenues from natural resources. In Myanmar's case, there are major unexploited investment opportunities, but the country also faces absorptive capacity constraints, the possibility of Dutch disease and price uncertainties. All these considerations need to be taken into account using a sustainable investing or other analytic tool, such as the tool developed by the IMF, that takes into account in a macroeconomic model, factors including the productivity of public investment, absorptive capacity, fiscal and capital sustainability, Dutch disease effects, and volatility in natural resource revenues. Finally, and depending on the absolute level of revenues in the future, it may be important for Myanmar to consider instruments, such as Stabilization and Sovereign Wealth Funds, which in other country contexts have proven extremely successful in reducing the exposure to macroeconomic risk and fostering investment (Box 5). 


\section{Box 5: Natural Resource Management, International Experience}

Chile has perhaps one of the most successful experiences in terms of natural resource management. The country controls more than $40 \%$ of the world's copper market, but its economy has managed to remain fairly stable and to diversify greatly over time. There have been two key ingredients that make Chile such an interesting case study. The first element was clear and transparent fiscal rules, which made government spending less procyclical and more sustainable. The second element was a Stabilization Fund, used to save resource revenues during windfalls and raise public savings, stimulating private savings and investment.

Botswana is another very successful resource-rich country. Although it is heavily dependent on the diamond trade, the country "has been one of the fastest growing in the world over the last 50 years." The most striking feature of the country's natural resource management strategy is the way in which natural resource revenues are handled. If resource revenues are employed for the funding of state projects, these have to pass very strict social cost-benefit analysis. These revenues are also channeled into the Community-based Natural Resources Management, an institution devoted to rural development, community mobilization, and institutional and enterprise development

Sources: Van der Ploeg and Venables 2013, Botswana Community-Based Natural Resources Management Support Programme website.

\section{B. State-Owned Enterprises}

Reform of Myanmar's Union Business Organizations, also known as SEEs, has been ongoing for some time. More than 700 SEEs have been privatized since the late 1990s and today, there are only 44 SEEs, of which 40 are "budgetary units" 6 and 4 are "autonomous units" in the process of being corporatized. In aggregate, however, the remaining SEEs are still very large (gross revenues are expected to exceed 9 trillion kyats or $\$ 9$ billion in FY2014) and cover a wide range of sectors, including extraction of natural resources (almost half of total SEE activity), power, telecommunications, and industry. ${ }^{8}$ In aggregate, they are also very profitable (revenues are expected to exceed expenditures by about 700 billion kyats in FY2014), although this figure should be treated carefully as there are significant differences in balances across ministries, and many ministries with negative balances, implying that there are still many loss-making SEEs. ${ }^{9}$ The SEEs primarily contribute to the Union's budget through two fiscal instruments. The first is the profit tax applicable to all enterprises (both public and private) at a $25 \%$ rate. The second instrument is a form of Union Dividend, consisting in a direct transfer of $20 \%$ of the profits of SEEs to the government budget. The remaining share is either used to self-finance investment, or is transferred to the Union.

SEEs are expected to continue to contribute substantially to the Union's budget for many years to come, through the expansion of enterprises in key sectors, such as natural resources, and through efforts to improve the efficiency of SEEs. Steps have been taken in the direction of a more corporatized SEE sector (Box 6). For example, in the past, enterprises were allowed to finance their deficits through transfers from the Union or from the CBM. This is no longer an option and Myanmar's SEEs are now operating under harder budget constraints, reducing the Union's fiscal risk and stimulating greater productivity (Cebotari et al. 2009). The government now needs to complete the corporatization of the four autonomous units and move other budgetary units into the autonomous/corporatization category, and outside of the government budget. It will also be important that the Budget Department

6 SEEs that are budgetary units have separate revenues and expenditures from their supervising ministry, and are in line for further transition to being autonomous units.

7 The four SEEs that have been made autonomous units are all under the Ministry of Transport: Inland Water Transport, Myanmar Ports Authority, Myanmar Shipyards, and Myanmar Airways.

8 SEEs under the Ministry of Defense are excluded from this analysis due to unavailability of data.

9 The data published in the official Gazette report SEE's activity aggregated at the ministerial level. 
in the MoFR completes the process of setting up a SEEs Monitoring Unit with the purpose of improving transparency and imposing adequate expenditure ceilings and that the sectoral ministries strengthen their own capacity to monitor the performance of the SEEs under their responsibility.

\section{Box 6: State Asset Reform Options}

\section{Corporatization}

This term describes the process of turning state's asset and liabilities into a corporation, with the government retaining at least majority, if not full, ownership. The main feature of this process is that it creates separate and independent economic entities, endowed with managerial autonomy, staffed using processes that are different from the civil service, and subject to the transparent reporting duties prevailing within the private sector

\section{Privatization}

Privatization takes the above process one step further, fully transferring the ownership to the private sector. The advantages of pure private ownership — maybe under government sectoral regulation-lie in the increased dynamic efficiency of the transferred assets, which in turn depends on the type of assets and the way in which privatization is managed (e.g., through auctions, IPO or negotiated contracts).

IPO = initial public offering.

Sources: Public-Private Partnership in Infrastructure Resource Center for Contracts, Laws and Regulations website; Shirley 1992.

It is also important that the government carefully considers the scope for further privatization of SEEs, bearing in mind that while government ownership can certainly be justified in sectors where natural monopolies exist, in other sectors, it may hamper competition. Moreover, while the most recent rounds of privatization have been targeted toward loss-bearing enterprises, the government needs to integrate the further restructuring and possible privatization of SEEs into its broader fiscal management and economic development strategy.

The government needs also to further review the privatization process in light of the experience of other countries. "Privatization done in the right way, or under the right circumstance, can have huge positive effects, but privatization can also be hugely detrimental" (Djankov and Murrel 2002). A key objective of privatization should be to encourage enterprises to restructure and innovate. This will depend very much on whether the new owners are active investors, connected with international markets, and able to quickly and efficiently restructure firms while generating knowledge spillovers. International experience shows that where the new owners do not have such capabilities, the expected benefits of privatization in terms of growth, employment, and income distribution have not been realized (Birdsall and Nellis 2003). Accordingly, the government's future privatization strategy should endeavor to avoid both the concentration of assets with preexisting managers and elites (Djankov and Murrel 2002), and an excessively dispersed ownership that might retard the decision making process.

\section{Tax System}

The tax effort in Myanmar has lagged behind comparable efforts in other ASEAN countries (Table 7). The government's budgeted tax yield was projected to increase from 3.1\% of GDP in FY2012 to 4.6\% in FY2013, and the actual tax yield (after taking account of the supplementary budget) is estimated at $6.4 \%$ of GDP in FY2012 and 6.6\% of GDP in FY2013. But this will still be one of the lowest levels of tax yield in the world. Buoyant revenues from natural resources have probably retarded reform efforts and 
encouraged widespread use of tax incentives for nonrevenue purposes..$^{10}$ In addition, Myanmar's tax system is complex and compliance is extremely low due to lack of knowledge and administrative bottlenecks.

\section{Table 7: Tax Revenues, Selected ASEAN Countries (\% of GDP)}

\begin{tabular}{|l|c|c|}
\hline Country & $\mathbf{2 0 1 1}$ & $\mathbf{2 0 1 2}$ \\
\hline Cambodia & 10 & 12 \\
\hline Indonesia & 12 & 15 \\
\hline Lao PDR & 14 & 16 \\
\hline Malaysia & 15 & 16 \\
\hline Myanmar & $\ldots$ & 3 \\
\hline Philippines & 12 & 13 \\
\hline Singapore & 14 & 14 \\
\hline Thailand & 18 & 16 \\
\hline
\end{tabular}

... = no data available, ASEAN $=$ Association of Southeast

Asian Nations, GDP = gross domestic product,

Lao PDR = Lao People's Democratic Republic.

Source: World Bank, World Development Indicators

(accessed December 2014).

Currently, the government employs a range of tax instruments. The most important are the Commercial Tax on Consumption" and the Personal Income and Profit Tax levied on both SEEs and the private sector (Table 8). Together, these instruments generated 95\% of total tax revenuesequivalent to 2.9\% of GDP in FY2012. In FY2014, the balance between different revenue items has been significantly altered by the licensing of telecom operation to two private firms that will rent the pre-existing state-owned infrastructure. Taxes on the usage of national properties paid by the two operators will amount to a quarter of total expected tax revenues.

Economic growth, higher foreign and domestic investment, increasing volumes of trade, and higher domestic consumption will be factors contributing to an increase in tax revenues. However, as noted in Section II, financing Myanmar's reform agenda and antipoverty policies will require a major increase in the share of government expenditures in GDP, which will need to be financed by a major increase in public revenues. Recognizing the importance of these considerations, the government has set a target of a $10 \%$ tax-to-GDP ratio by 2018 . This would seem to be a feasible target but will likely require deep reform of the tax system, including simplifying the system and easing administrative constraint to collection (World Bank 2013), extending enforcement and creating incentives for compliance, and expanding the coverage of the existing tax instruments. The government should also avoid, as much as possible, using the tax system for nonrevenue purposes. Widespread use of tax incentives to boost capital accumulation and consumption of certain goods is usually a suboptimal choice, as it delivers poor results in terms of investments and complicates the tax system, raising

10 New investments, both local and foreign, enjoy a sensible amount of tax incentives under the Foreign Investment Law and the Myanmar Citizen Law.

1 The Myanmar Commercial Tax is a general consumption tax levied at a rate of $5 \%$ on potentially every transaction. A few excisable luxury goods are subject to higher rates. To avoid cascading, commercial tax paid on intermediate inputs qualifies for reimbursement. 
administrative costs and hurting compliance. Moreover, tax incentives are an instrument that is difficult to narrowly target, unlike expenditure programs.

\section{Table 8: Government Tax Revenues ${ }^{a}$}

\begin{tabular}{|l|r|r|r|r|r|c|c|}
\hline & FY2013 & FY2014 & Growth & FY2013 & FY2014 & FY2013 & FY2014 \\
\hline & \multicolumn{2}{|c|}{ Kyats billion } & \multicolumn{2}{c|}{$\%$} & \multicolumn{2}{|c|}{$\%$ of total } & \multicolumn{2}{|c|}{$\%$ of GDP } \\
\hline $\begin{array}{l}\text { Domestic products and public } \\
\text { consumption tax }\end{array}$ & 1,200 & 1,464 & 22 & 46 & 30 & 2 & 2 \\
\hline Tax on income and property & 1,265 & 1,665 & 32 & 48 & 34 & 2 & 3 \\
\hline Customs & 135 & 190 & 41 & 5 & 4 & 0 & 0 \\
\hline $\begin{array}{l}\text { Tax on usage of national } \\
\text { properties }\end{array}$ & 8 & 1,571 & 18,943 & 0 & 32 & 0 & 3 \\
\hline $\begin{array}{l}\text { Total tax revenues (excluding } \\
\text { transfers from SOEs) }\end{array}$ & 2,608 & 4,890 & 87 & 100 & 100 & 5 & 8 \\
\hline
\end{tabular}

${ }^{a}$ These are the original budget numbers. The final numbers for the year are significantly higher after taking account of the supplementary budget.

$\mathrm{FY}=$ fiscal year, GDP = gross domestic product, $\mathrm{SOEs}=$ state-owned enterprises

Sources: IMF 2014, Union Government of Myanmar 2014.

Increasing the share of public revenues accruing from taxation would also improve the limited elasticity ${ }^{12}$ of Myanmar's revenue system, allowing government resources to keep up with the increasing expenditure needs of the economy. Moreover, the composition of public revenues needs to change to accommodate Myanmar's macroeconomic and structural transformation. The discussion in Section II suggests that future budgets will witness an increasing presence of fairly inflexible current expenditures; these will need to be financed through equally stable recurrent revenues, i.e., taxes. Capital revenues are inherently more volatile and connected to depletion of public capital and natural resources. International experience demonstrates that a mismatch between the nature of revenues and public expenditure (current versus capital) has been at the heart of several macroeconomic and debt crises, hampering the sustainability of growth patterns in several Latin American and African countries.

It may be appropriate for the government to consider shifting the balance more toward indirect taxes through more widespread enforcement of a flat and simpler consumption tax (Tanzi and Zee 2000). The common argument in favor of indirect taxation, in fact, stresses the importance of sales taxes as an instrument to earn public revenues, even from incomes that escape direct taxation. ${ }^{13}$ Moreover, taxing consumption, being inherently more stable than income, will provide more stability to the country's revenue system. From the private sector perspective, compliance with sales taxes could

12 In brief, a revenue system is defined as income elastic if collected revenues grow with the economy: they increase-or at least remain constant-as a share of GDP. Revenues from natural resources are inherently connected with a country's geological structure and exploration activity. While these receipts have been substantial and increasing over the last 5 years, the medium- to long-term trend is bound to correlate only marginally with the country's GDP. On the other hand, revenues from almost all other tax instruments (under a set of conditions on the tax base) are bound to accrue an increasing — or at least constant-amount of revenues as a share of GDP.

13 The argument against indirect taxation, instead, points at its potential regressive impact on income distribution, as consumption represents a much larger share of disposable income for poor households. However, this is unlikely to happen in Myanmar over the medium-term, as sale taxes will mainly be enforced in urban areas and on the formal or modern sector, and could potentially encompass a zero-rate for goods such as staple foods or items consumed disproportionately by the poor. 
also contribute to the development of the accounting and audit systems required for compliance with direct taxation. The new Union Taxation Law, enacted in April 2014, has changed commercial tax to a simple 5\% tax imposed on all sales of most goods, with no opportunity for producers and distributors to claim drawback on inputs. While in the long run, it is best for Myanmar to move to a VAT type system that allows drawback, given current capacity constraints, this move is a sensible one and should enable increased revenue collection without being too distortionary. However, the gains from this change are offset by most domestic firms being given special treatment and only having to pay $2 \%$ commercial tax-this will lower revenues, both directly and indirectly by introducing hard to monitor complexity. Some other undesirable exemptions and amnesties have also been introduced in the new Union Taxation Law.

Currently, goods that are commonly treated as excisable goods in many countries (e.g., petroleum products, gas, tobacco products, alcohol, motor vehicles, gems) are taxed under the commercial tax, but at a higher rate (8\%-100\%). The intention of the law is that they are only to be taxed at this higher rate once along the supply chain, but it is unclear at which point this is supposed to happen, and evasion is widespread. Revenue collection on these goods could be dramatically improved by treating them separately as excisable goods, with excise tax collected once, either at the point of importation (for imported goods) or the point of production (for domestically produced goods), and then the standard rate of commercial tax applied at subsequent stages in the supply chain.

With respect to direct taxation in the form of income and profit taxes, reducing the number of exemptions and simplifying the tax structure can deliver significant improvements in compliance. The new Union Taxation Law includes several important steps toward simplifying direct taxation. For personal income tax, five brackets and a raised threshold, have replaced the previous unwieldy system of 12 brackets. The law also reduces differences in the rates at which different sources of income are taxed. These changes reduce the incentive for avoidance and misreporting, and can also allow the tax base to grow into the tax system as the country develops. Further reduction in the number of brackets for personal income tax, e.g., to two or three, would further improve the direct taxation system.

A comprehensive reform strategy will also be needed to tackle the multiple bottlenecks and administrative difficulties hampering tax collection and compliance. The steps taken to establish a Large Taxpayer Unit and reform/expand the taxpayer registration system should strengthen Myanmar's tax collection capacity, but further reforms should be added to the agenda. As reported in the Public Financial Management Performance Report, "a dedicated set of laws and legislation on tax and customs administration is lacking" (World Bank 2013, p. 58). Clear guidelines and more training should be provided to the tax collectors who are responsible for the case-by-case assessment of tax liabilities. Assessment of tax liabilities is often conducted using indicators rather than audited information provided by the taxpayers, increasing taxpayers' uncertainty over their liabilities. Moreover, the modernization of the tax administration should include a shift toward the use of selective audit tools, as opposed to the current assessment system, which increases tax collection costs and generates ample ground for corruption and rent-seeking. As a complement to this reform, the ongoing taxpayer education programs should be extended and strengthened. ${ }^{14}$

Finally, both the central and subnational governments should consider the significant benefits to be gained from the introduction of a tax on property. This fiscal instrument could increase the overall progressivity of the tax system and, being a tax better administered at the subnational level, could foster

14 For more details, see World Bank 2013. 
the process of fiscal decentralization. A necessary first step would be to set up a cadaster, which will help state and regional governments develop administrative capacity. An additional potential benefit of the introduction of property taxes is the possibility of reining in real estate prices. The additional revenues would also reduce the need for intergovernmental transfers and empower local governments.

\section{Foreign Aid and Borrowing}

With the opening up of the economy and the lifting of sanctions, Myanmar can expect to be receiving much increased flows of development assistance in the years ahead. Indeed on a per capita basis, net overseas development assistance (ODA) has already increased significantly from its previously very low level (Table 9), primarily as a result of arrears clearances. Despite this recent increase, the current level of ODA per capita is still far below that of comparable ASEAN countries. However, further increases are projected with multilateral donors such as Asian Development Bank (ADB) and the World Bank reengaging, and many bilateral donors either stepping up their ongoing programs or beginning new ones. International nongovernment organizations (NGOs) are also expected to increase their support. Unfortunately, the experience with effectively utilizing foreign aid and borrowing varies greatly across countries (Box 7). It is therefore very important that both the government and the donor community engage collectively, both to increase the level of support (in view of the urgent needs of the country) and to enhance its effectiveness, drawing on the Paris and Busan guidelines for aid effectiveness-host country ownership; alignment with host country objectives, harmonization among donors, resultsoriented aid, and mutual accountability.

\section{Table 9: Net Official Development Assistance Received per Capita}

(\$)

\begin{tabular}{|l|c|c|c|c|}
\hline & Cambodia & Lao PDR & Myanmar & Viet Nam \\
\hline FY2011 & 55 & 63 & 8 & 40 \\
\hline FY2012 & 52 & 80 & 28 & 39 \\
\hline
\end{tabular}

FY = fiscal year, Lao PDR = Lao People's Democratic Republic.

Sources: OECD-DAC; World Bank, World Development Indicators (both accessed July 2014).

In this regard, recent developments have been positive. ${ }^{15}$ In keeping with the principle of hostcountry ownership, the government put in place in 2012 its own systems and procedures for coordinating development support, with a Foreign Aid Management Central Committee chaired by the President and a Foreign Aid Management Working Committee chaired by a Senior Minister in the President's Office. MNPED (and more specifically the Foreign Economic Relations Department) has also geared up its activities and is meeting with donors on a regular basis. As a result, the government was able to organize and chair a successful first Development Cooperation Forum (MDCF) at the beginning of 2013, which endorsed the FESR as well as the Naypyitaw Accord for Effective Donor Cooperation, and another successful MDCF at the beginning of 2014.

The challenge now facing both the government and the donor community is to build on these positive developments and move to the successful implementation of agreed principles and actions. In this regard, the preparation and approval of sound sector strategies that are government-owned and around which donor support can be effectively coordinated, will be particularly important. External partners need to move as quickly as possible to a program approach and to using government systems

15 For further details, see Rieffel and Fox 2013. 
for support and helping strengthen those systems and build national capacity instead of using their own systems. Technical assistance from external partners should focus on building national capacity, not substituting for it. It will also be important that the systems the government has already put in place are used to coordinate support from all multilateral and bilateral partners as well as from international NGOs. All of this will require further strengthening of capacity within MNPED as well as institutional and capacity strengthening in the concerned line ministries. Finally, external partners should be encouraged to provide as much of their support as possible on a grant basis, or with very low interest on their loans to help with the external debt. In addition, and as already agreed with the IMF, nonconcessional borrowing should only be used to finance economically viable projects in priority sectors crucial to economic growth.

\title{
Box 7: Donor Coordination, Country Experience
}

\begin{abstract}
In Myanmar's regional peer group, recent studies, sponsored by the Organisation for Economic Co-operation and Development (OECD), of donor coordination in Nepal, Cambodia, and Viet Nam provide contrasting stories. All of the studies were carried out in 2010 in preparation for the Busan follow-up meeting to discuss progress in implementing the Paris Declaration and can be accessed from the OECD website.

In Nepal, aid commitments exceeded the country's absorptive capacity. Donor programs tended to be duplicative and sometimes inconsistent. In the words of the study, "the need to demonstrate attribution, a reluctance to align internal bureaucratic processes with those of [the Government of Nepal], and inadequate ownership and interest in the development process from Nepal are the main reasons given [for the ineffectiveness of aid]." Many projects had a standalone character, meaning that they left little footprint once the money was disbursed.
\end{abstract}

In Cambodia, the study reported a "high degree of fragmentation in aid delivery," partly due to lack of capacity in the government. This weakness was exacerbated by the diversity and complexity of donor programs, which overtaxed the government's management capacity. Fear of corruption was another factor, as donors mostly opted to use their own systems for monitoring and implementing their projects.

In Viet Nam, relatively little foreign aid was provided during the first decade after doimoi in 1986. When donor activity accelerated in the mid-1990s, the government established a strong unit to manage foreign aid to the country, and was successful in channeling aid in ways that reinforced government programs in rural areas. Initially, the central government directed most aid flows, but gradually, more control was delegated to the lower levels of government largely because of pressure from donors.

Source: Rieffel and Fox 2013.

\section{FISCAL DECENTRALIZATION}

Fiscal decentralization is an important component of the government's overall plans for regional development, decentralization and strengthening of local governance. In this regard, international experience suggests that decentralization can lead to significant benefits in terms of economic growth and poverty reduction while not endangering overall economic stability, so long as the process is carefully designed and well-implemented. Key to success is the careful management of the links between political, administrative and fiscal decentralization, and between decentralization and the peace process. Also critical is the design of the fiscal decentralization process itself, including clarity with respect to expenditure and revenue assignments, an efficient and equitable system of intergovernmental transfers, and a sound strategy for local borrowing as well as a good understanding of and an agreement on the links between fiscal decentralization and sharing natural resource wealth. 


\section{A. Links between Political, Administrative, and Fiscal Decentralization}

Myanmar's institutional structure at the level immediately below the national level is made up of seven states and seven regions (which are constitutionally equivalent) as well as five self-administered zones and one self-administered division, which have a constitutional status similar to a region or state. The smallest formal administrative unit is the village, with several grouped together into village tracts. Urban wards, towns, and village tracts are grouped into townships, where the lowest levels of government offices are generally located. Collections of townships are organized as districts, which in turn form the region or state. Currently there are 325 townships and 67 districts in Myanmar's states and regions.

In recent years, there have been important developments in the area of political decentralization. Under the 2008 constitution, each state and region now has a unicameral, partially elected state and region assembly, an executive led by a chief minister, a cabinet of state and region ministers, state and region judicial institutions, and its own budget from the central government (Ministry of Information 2008). These developments have opened up new opportunities for debate and discussion. However, chief ministers are still accountable ultimately to the president, not to their assemblies, the range of responsibilities of the new institutions remains somewhat uncertain and the resources at their disposal are still very small. There have also been significant political developments at the village or village tract level, with most now having elected their own village leaders to replace centrally-appointed village administrators. However, at the township level, where many key functions of government take place, and at the district level, there is no body of elected representatives, and both townships and districts continue to be headed by a senior official of the General Administration Department (GAD) of the Ministry of Home Affairs.

Administrative decentralization has also been moving ahead, but the division of responsibilities under Schedule Two of the Constitution is far from clear. There are 18-24 departments under the state and region governments, but there is no clear separation of roles and responsibilities between the region and state departments and the union departments at the region and state level. Moreover, major service delivery departments, such as health and education as well as GAD (which is primarily responsible for administration and bottom-up participation starting from village level), are still under the management of the Union Government-although some are now starting a process of deconcentration by giving more authority to lower administrative levels.

The lack of clarity with respect to administrative responsibilities is complicating the process of fiscal decentralization, which is taking place in a mixed and limited way. State and region governments are now preparing their own budgets, but they cover only the income and expenditures of those departments and state economic entities that are associated with those governments-and in total, represent less than $5 \%$ of the public spending that actually takes place in the states and regions. Moreover, control over budget composition and priorities is still limited and centralized, there is limited scope for states and regions to prioritize between sectors, and decision making with respect to the budget is largely the responsibility of the centrally appointed chief ministers and the Union Financial Commission. ${ }^{16}$

16 The following discussion of states and regions draws significantly from Nixon et al. 2013. 
In sum, decentralization in Myanmar is moving ahead in a limited but significant way, with political decentralization moving ahead of administrative and fiscal decentralization, and with insufficient clarity on the linkages between the three. In these respects, Myanmar's experience is similar to the experience of other countries embarking on the process of decentralization, which reinforces the potential value of learning from the lessons of international experience with respect to the way forward. Such critical lessons include, the centrality of politics to the process, the importance of commitment to reform, the need for custom solutions, even at the regional level. Most importantly, there are some universal requirements for effective decentralization. These include: a broad vision of what the decentralized system should be and what it is expected to accomplish over time; an initial framework that defines key components of the system and the linkages among them; and a pragmatic strategy for bringing the system into existence and for adjusting and supporting its evolution over time (European Commission 2007). In preparing the vision, framework, and strategy, it is also important that the linkages among the three dimensions of decentralization are well-integrated. The division of power across different levels of government and society needs to be appropriately reflected in the division of fiscal responsibilities, administrative systems and procedures need to be in line with the execution of political power and fiscal tasks, and fiscal arrangements need to prevent a clashing of political and administrative powers. Finally, decentralization needs to be closely linked with the peace process.

\section{B. Pillars of Fiscal Decentralization}

Fiscal decentralization can be looked at in terms of four basic building blocks or "pillars" (UNDP 2005). First is the assignment of expenditure responsibilities to different government levels. Second is the assignment of tax and revenue sources to different government levels. Third is intergovernmental transfers-central governments may provide regional and local governments with additional resources through a system of intergovernmental fiscal transfers or grants. Fourth is the issue of subnational borrowing and whether local governments are permitted to borrow to finance revenue shortfalls.

The first step in the design of a system of intergovernmental fiscal relations should be a clear assignment of functional and expenditure responsibilities among different levels of government (McLure and Martinez-Vazquez 2000). Unfortunately, the current legal framework leaves considerable ambiguity as to the expenditure responsibilities across different sectors. Many government departments are included under both schedule one (union) and schedule two (state and region), and many others are not included at all (Table 10). International experience suggests that there is no single "best" assignment of expenditure responsibilities among different government levels. In addition different levels of government may need to be simultaneously involved in the same broad service area (e.g., primary education) but in different ways (e.g., local governments are responsible for the direct provision of primary education services, while central government is responsible for defining curricula, overseeing standards, and perhaps financing the sector). But it is critically important that responsibilities are clearly defined in detail. International experience also suggests using the "subsidiarity principle" in making such determinations-meaning that government functions should be assigned to the lowest level of government that is capable of efficiently undertaking the function; this approach ensures that spillovers from the service are minimized. Any final determination of expenditure assignments will also need to be well-linked with broader agreements on the overall decentralization process, which will help to determine how much subnational spending will be achieved through fiscal deconcentration of currently centralized line ministries (e.g., those specified in Schedule I), and how much through devolution to state and regional governments and budgets. 
Table 10: State and Region Budget Units and Constitutional Assignments

\begin{tabular}{|c|c|c|c|}
\hline Departments Appearing in State and Region Budget & $\begin{array}{l}\text { Schedule I } \\
\text { (Union) }\end{array}$ & $\begin{array}{c}\text { Schedule II } \\
\text { (State/Region) }\end{array}$ & $\begin{array}{l}\text { Residual/ } \\
\text { Uncertain }\end{array}$ \\
\hline General Administration Department & $\sqrt{ }$ & & \\
\hline Special Investigation Department & $\sqrt{ }$ & & \\
\hline Prison Department & $\sqrt{ }$ & & \\
\hline Settlements and Land records Department & $\sqrt{ }$ & & \\
\hline Department of Agriculture & $\sqrt{ }$ & $\sqrt{ }$ & \\
\hline Department of Industrial Crops Development & $\sqrt{ }$ & & \\
\hline Cooperative Office & $\sqrt{ }$ & & \\
\hline Department of Small Scale Industries & & & $\sqrt{ }$ \\
\hline Fisheries Department & & & $\sqrt{ }$ \\
\hline Department of Livestock and Veterinary & & & $\sqrt{ }$ \\
\hline Department of Beekeeping & & & $\sqrt{ }$ \\
\hline Department of Human Settlement and Housing Development & & $\sqrt{ }$ & \\
\hline Maintenance of Buildings, Roads, and Bridges & & & $\sqrt{ }$ \\
\hline Public Construction & $\sqrt{ }$ & & $\sqrt{ }$ \\
\hline Budget Department & $\sqrt{ }$ & $\sqrt{ }$ & \\
\hline Department of Planning & $\sqrt{ }$ & $\sqrt{ }$ & \\
\hline Central Stevedoring Committee & & & $\sqrt{ }$ \\
\hline Forestry Department & $\sqrt{ }$ & & \\
\hline Dry Zone Green Project Development & $\sqrt{ }$ & & $\sqrt{ }$ \\
\hline Department of Sports and Physical Education & $\sqrt{ }$ & & \\
\hline Water Transport Development & $\sqrt{ }$ & & \\
\hline Municipals & & $\sqrt{ }$ & \\
\hline Myanmar Film Making & $\sqrt{ }$ & $\sqrt{ }$ & \\
\hline Myanmar Salt and Marine Chemical Enterprise & $\sqrt{ }$ & $\sqrt{ }$ & \\
\hline Myanmar Pharmaceutical and Foodstuff Industry & $\sqrt{ }$ & & \\
\hline Home Utilities Industry & & & $\sqrt{ }$ \\
\hline
\end{tabular}

Source: Nixon et al 2013.

Revenue assignments are set out in Schedule $V$ of the Constitution. There are 19 tax headings under the schedule but currently the region and state governments are allowed to collect under nine headings, while the budget headings indicate only seven sources of tax revenues: excise tax, land tax, embankment tax, forestry tax, mining tax, lakes/streams tax, and municipal tax. The total amount of taxes collected from these sources by region and state governments is currently about $4 \%$ of total government revenues, with variations from 13\% in Mandalay Region to $0.7 \%$ to Rakhine State, a reflection in part of the differing levels of economic development across states and regions. ${ }^{17}$ For almost all states and regions, the municipal tax is either the first or the second most important revenue source. International experience suggests that local governments should be assigned stable sources of revenue that are easy to administer and clearly separable across different local jurisdictions; and commonly agreed examples of such sources include: real estate property taxes, retail sales taxes, business fees, motor vehicle fees, and user charges. From this perspective, the current list of local taxes for Myanmar would seem to be a good beginning, but will need to be reviewed in the context of the overall reform of the government's tax policy as well as the future directions for decentralization. Of

17 Extracted from 2012-2013 State and Region Budgets, as reported in the official Gazette. 
particular importance will be the outcome of the peace negotiations and any agreements reached in that context on sharing of natural resource wealth.

Since the assignment of revenue sources rarely provides local governments with sufficient revenues to fund their expenditure functions, intergovernmental transfers are often necessary. This is the case in Myanmar, where there are currently two types of unconditional/conditional transfer: grants for poverty reduction, under which one billion kyat was distributed in FY2012 evenly to all regions and states (except for Chin State, which receives three times more than other regions and states because of its high poverty rate and difficult transportation situation); and other grants primarily for the purpose of helping regions and states "balance their books" (Figure 4). In total, these two types of transfers are very small and are far outweighed by the funding provided directly by union ministries. The system of intergovernmental transfers does, however, require a major review, (the World Bank (2013) has noted that it is "neither rules-based nor transparent") and in this regard, Myanmar can draw on a wealth of international experience of use for such transfers, including "vertical" or "horizontal" balance, funding specific national priorities, counteracting effects of interregional spillovers or externalities, etc., the form in which such transfers are made (conditional or unconditional), and some universally accepted principles of transfer design (Box 8). The development of the transfer system in Myanmar will also be crucially dependent on broader decisions taken with respect to decentralization, including how much subnational spending will be achieved through deconcentration versus devolution to regions and states, and how natural resource wealth is to be shared.

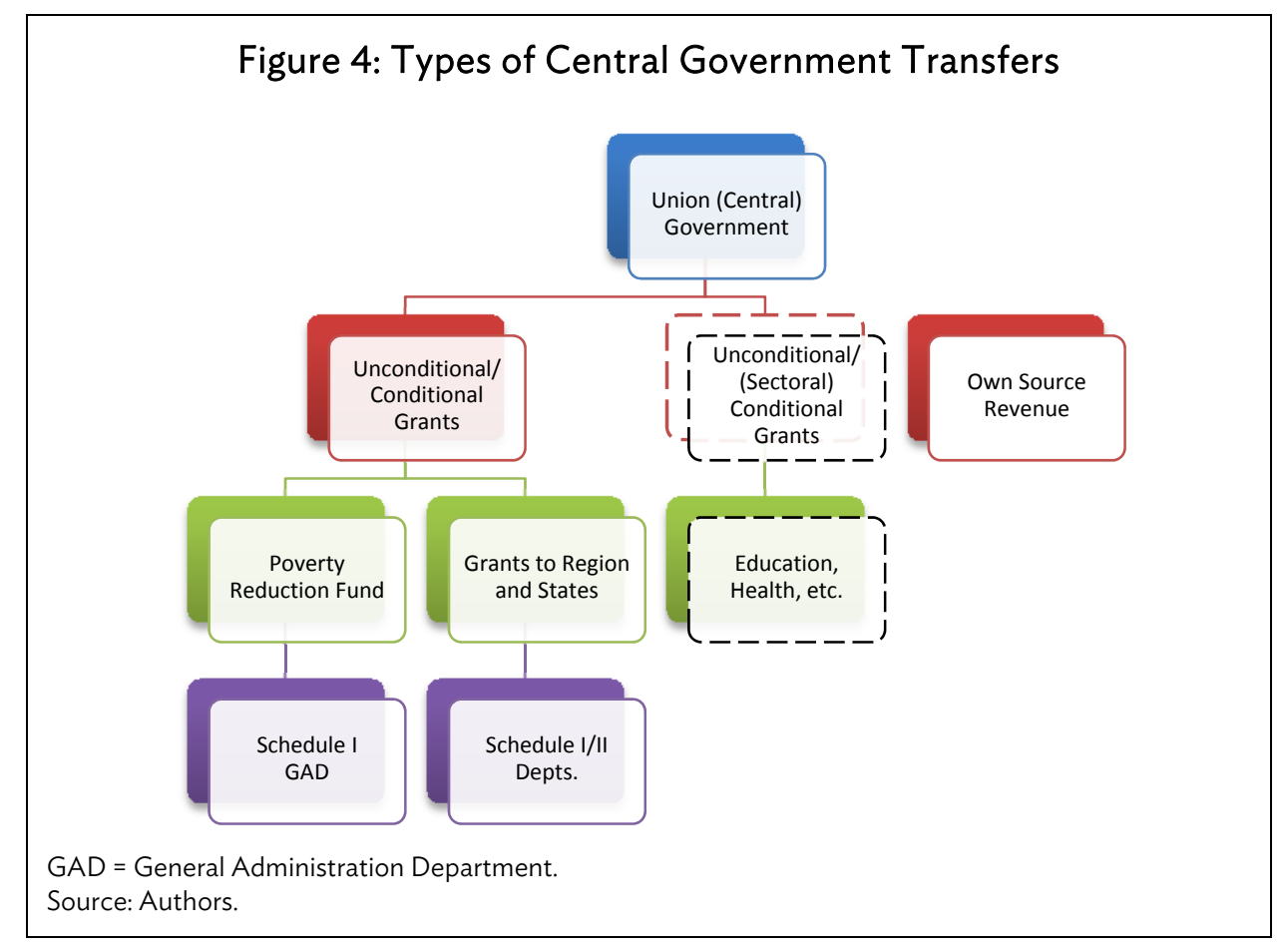

The fourth and final pillar of decentralization is subnational borrowing. At present, the debt recorded as being incurred by regions and states appears to relate to union support for the operating deficits of SEEs, and in general, regional and state governments are reluctant to borrow because of an inability to repay. To avoid any possibility that imbalances at the regional and state levels could impact on macroeconomic stability, it will be important to put in place a well-defined framework for any local borrowing that may be permitted. 


\section{Box 8: Principles of Transfer Design}

Providing revenue adequacy. A transfer formula should, as far as possible, provide a source of adequate resources for local governments.

Preserving budget autonomy. A transfer system should preserve budget autonomy at the subnational level within the constraints provided by national priorities.

Enhancing equity and fairness. The transfer mechanism should support a fair allocation of resources.

Stability. Transfers should be provided in a predictable manner over time.

Simplicity and transparency. Transfer formulas should be simple and transparent, and should pursue one objective at a time.

Incentive compatibility. The transfer system should not create negative incentives for local revenue mobilization, and should not induce inefficient expenditure choices.

Focus on service delivery. Transfer formulas should focus on the demand (clients or outputs) rather than the supply (inputs and infrastructure) of local government services.

Avoid equal shares. Reliance on the "equal shares" principle (whereby all local governments at the same level, whatever their size and characteristics, receive the same size of transfer) as a major allocation factor should be avoided in the design of an allocation formula.

Avoid sudden large changes. The transfer system should avoid sudden large changes in funding for local governmentsespecially during the introduction of a new transfer mechanism.

Grants should be announced in a timely manner corresponding to the local budget cycle.

Source: UNDP 2005

The government will also need to review both the system and the capacity for preparing, approving and implementing the budget. Since FY2012, region and state governments have been accountable for preparing their own budget proposals with a participatory budgeting approach. Departmental expenditures were estimated based on previous years' expenditures and budget proposals, and estimated expenditures sent to the Finance and Revenue Department and the Planning and Economic Development Department for review. The Budget Department has scrutinized the budget and consolidated the current, capital and financial budget with the regions and states budget allocation; and the Planning and Economic Development Department has made sure the budget was in line with proposed local development projects. The budgets have then been submitted to the MoFR and MNPED for review, after which, the Financial Commission has vetted the budgets of both the Union and regions and states before submitting the bill to Pyidaungsu Hluttaw, where the final decisions on the amount of budget to be allocated for each region and state have been made (Ministry of Information 2008). It will also be necessary to consider what guidelines should be introduced at the different levels of the system to help with budget preparation, approval, and implementation and how best to strengthen the capacity at different levels to effectively use the guidelines and manage the system.

In sum, significant developments are taking place across all aspects of fiscal decentralization. Drawing on lessons of international experience (Box 9), it will now be important to carefully review experience with decentralization and its management. 


\section{Box 9: Fiscal Decentralization, Lessons of Country Experience}

The sequencing of decentralization matters: resources should be made available to subnational governments pari passu with the assignment to them of spending responsibilities.

The pace of decentralization should be linked as much as possible to the capacity of subnational governments to effectively carry out the functions assigned to them.

While spending responsibilities in some sectors (such as education and health) will inevitably overlap across levels of government, it is important to ensure adequate clarity of the role of each level of government in the provision of the services, to avoid duplication, waste, and loss of accountability.

In some cases, complementary policy reforms are also needed, such as in the civil service and regulatory frameworks.

Realizing the potential efficiency gains of decentralization in the provision of public goods and services often requires significant investments in capacity building and improvement of PFM systems at the subnational level, in particular, aiming at improving transparency of the budget process in all its phases.

In order to facilitate the effective implementation of a "hard budget constraint" on subnational governments, the latter must be provided with an overall resource envelope that ex ante would allow them to carry out their assigned spending responsibilities at an average level of efficiency.

Control over a portion of subnational resources is key to promoting accountability of those governments to their constituents as well as fiscal responsibility.

As subnational's own resources typically fall well short of spending responsibilities, intergovernmental transfers are needed to offset the resulting vertical imbalances.

Intergovernmental transfers are also used to moderate horizontal imbalances within each level of government.

Limits to subnational borrowing are in most cases needed to ensure adequate fiscal discipline.

To enforce any form of control, availability of relevant information is crucial, including on floating debt and contingent liabilities (especially guarantees and PPPs).

PFM = public financial management, PPPs = public-private partnerships.

Source: IMF 2009.

\section{Fiscal Decentralization and Sharing Natural Resource Wealth}

As noted above, the discussions on fiscal decentralization in Myanmar need to be linked with the peace-building process. The peace process will focus on many issues relevant to decentralization, particularly the sharing of natural resource wealth.

Many of the regions of Myanmar that have been affected by conflict are particularly natural resource rich. International experience suggests that addressing wealth sharing in the peace process can help end armed conflict over natural resources, preventing a renewal of hostilities, and providing the prospect of a better future after armed conflict. But international experience also suggests that this is a difficult process and that wealth sharing arrangements need to be carefully designed and implemented. This will likely require: defining what is to be shared and how; generating and sharing information; being as inclusive as possible in the negotiations process, and presenting wealth sharing as an incentive for peace. It may also be desirable to leave open the question of the ultimate ownership of the natural resources (Box 10). 


\section{Box 10: Constructing Wealth-Sharing Arrangements}

Define what is to be shared and how. A clear understanding of which resources are to be involved and the precise mechanisms by which wealth will be shared can prevent difficulties during the peace process and postconflict implementation.

Generate and share information. Creating and sharing information on the value and future prospects of natural resources is important to managing expectations and ensuring that all parties are equally well-informed.

Allow ownership of resources to remain unresolved. To maintain the momentum of negotiations, it may be desirable to allow resource ownership to remain unresolved and to focus instead on wealth sharing.

Be inclusive - but do not allow negotiations to be undermined by spoilers. Wealth-sharing negotiations may make a more lasting contribution to peace if they are as inclusive as possible — that is, if the negotiators and their constituencies feel ownership of the agreements.

Present wealth sharing as an incentive for peace. By ensuring that all parties enjoy equivalent gains from natural resources, wealth-sharing agreements can override animosities and increase security.

Source: Wennmann 2012.

It will also be important that the rules governing the process of wealth sharing are clear and specific. In this regard, there are three broad approaches to revenue collection and distribution that can be considered. First is the collection of revenues into a single account and the sharing of those resources between different levels of government in accordance with an agreed formula. Second is the allocation of the right to directly collect certain types of revenues to state or local governments, and certain types to national governments. Third is some combination of the first two approaches. Specific arrangements vary greatly from country to country. In this context, Myanmar can draw on the lessons emerging from these varied approaches and experiences but will need to consider what specific arrangements will be optimal for its unique circumstances.

\section{MACRO FISCAL LINKAGES}

After many years of poor fiscal policy resulting in macroeconomic instability, it is essential that the links between fiscal policy and broader macroeconomic policies are well-understood and managed. Fiscal policy has important implications for growth and for poverty reduction. There are fiscal risks that need to be assessed and appropriately addressed. The budget deficit needs to be maintained at a prudent level and soundly financed. All of this will require further improvements in macro-economic management and coordination, especially between the MoFR and the CBM.

\section{A. Fiscal Policy for Stability, Growth, and Poverty Reduction}

The government is committed to maintaining the consolidated public sector deficit at around 5\% of GDP which, together with appropriate monetary policies, should help ensure that inflation remains at a low level. It is not possible to determine precisely the appropriate level of the deficit. Indeed, many factors need to be taken into account, including developments in macroeconomic indicators (growth, savings, inflation, etc.); existing levels of debt; and the extent to which deficits are being used to finance capital investments, as opposed to current expenditures, etc. Accordingly, what will be important is that the government keeps the overall target for the deficit under review, in light of broader economic 
developments, and adjusts it as necessary. In the context of the overall reform of the public sector and the separation of SEEs from the government budget, consideration should also be given to establishing a deficit target for the government budget as opposed to the consolidated public sector budget.

As discussed in Section II of this paper, government expenditures on the social sectors, as a proportion of GDP, are still very low compared to other ASEAN countries. It is also clear that Myanmar requires major investments in infrastructure to catch up with the levels of infrastructure in neighboring countries. Moreover, expenditures on the social sectors and infrastructure are critical to the government's overall objectives of accelerating growth and reducing poverty. As discussed in Section II, some of the additional expenditures needed for the social sectors and infrastructure can come from a reallocation of public expenditures. However, such a reallocation can only take place gradually and will be insufficient to permit the growth in expenditures that is required to address the huge backlog of needs and move public spending on these sectors to a level comparable to that of other developing countries.

Accordingly, it is critical to Myanmar's future development that resource mobilization is accelerated as rapidly as possible with a particular emphasis on tax revenues, as noted in Section III. In this regard, the government has set a target of achieving a 10\% tax-to-GDP ratio within the next 5 years, but this would still leave the ratio below that prevailing in all the other ASEAN countries. Moreover, the latest IMF projections of the overall revenue-to-GDP ratio show it increasing relatively slowly from 9.1\% in FY2012 to 10.9\% in FY2018 - again much below comparable ratios for other ASEAN countries and a reflection of the challenge the government faces in respect of both policy and administration.

Of course, additional expenditures on the social sectors and infrastructure will only contribute to growth and poverty reduction if they are well spent. So at the same time as the capacity for tax administration is being enhanced, it will be critical to be enhancing the government's overall capacity in the social sectors and in infrastructure for policy and program design, and implementation.

\section{B. Management of Fiscal Risks}

Fiscal risks-meaning an unexpected event that adversely impacts an established fiscal framework-are a reality for all countries, including Myanmar. The sources of such risks include economic assumptions that prove to be incorrect, the structure of government debt, state guarantees, PPPs, and natural disasters. Identification and appropriate management of these risks is critical to longer term fiscal sustainability.

With respect to inaccurate economic assumptions, the most significant fiscal risks for Myanmar likely relate to assumptions about oil and gas (and possibly other commodities) prices, assumptions about the exchange rate, and assumptions about the profitability of state enterprises. To address these risks, it will be important to fully disclose the price and other assumptions that have been made; undertake sensitivity analysis; and where appropriate, make provision for reserve or contingency funds. The key risk characteristics of government debt include: short-term versus long-term debt, variable versus fixed interest rates, and foreign versus local currency-denominated debt. These risks need to be managed through an explicit debt management strategy (Section V.C). State guarantees, which can include institutional guarantees, such as for student loans or housing, as well as one-off guarantees for individual projects, run the risk of default and need to be managed through transparent reporting, clear procedures for authorization, risk sharing, and integration with the annual budget process. PPPs face similar issues to state guarantees but are even more complex, which is why specialized PPP units and the integration of PPP decisions with the annual budget process are essential. Finally, with respect to natural disasters, it will be important to consider preventive measures as well as mandatory insurance or government contingency funds. 
A review of country experiences (Box 11) suggests some broad guidelines for managing such risks. First, it is critical that the risks are identified and disclosed. This will also help improve the quality of decisions on whether the government should take on the risk in the first place. Second, a clear policy framework should be in place for assessing whether the government should take on a fiscal risk and how that risk should be mitigated in a cost-effective manner. Third, there should be a clear legal and administrative framework to regulate the government's overall exposure to fiscal risks, as part of the regulation of the overall fiscal framework. In this regard, it is likely to be beneficial to charge a central unit in the MoFR with the necessary authority and accountability for monitoring the overall level of fiscal risk and coordinating its management. Finally, fiscal risks should be incorporated into the fiscal analysis and the budget process, and appropriate measures should be put in place to cope with unexpected reductions in revenues or increases in expenditures.

\section{Box 11: Fiscal Risk Management, Review of Country Experiences}

A number of broad messages emerge from a review of country experiences.

- Effective identification of fiscal risks requires a clear allocation of responsibilities for the various parts of the public sector in assessing and reporting fiscal risks and that procedures are in place to ensure that the entity that plays the main role in determining fiscal policy (typically, the Ministry of Finance) has access to relevant data.

- Comprehensive disclosure of fiscal risks is desirable to facilitate identification and management of risks. However, disclosure modalities in some areas should avoid engendering moral hazard from a perception of implicit blanket guarantee (e.g., in the banking system) and ensure the state's economic interests are not prejudiced.

- Cost-effective mitigation begins with sound macro-economic policies and public financial management practices. It also consists of practices that require justification for taking fiscal risks, and that make it necessary for private sector agents to pay guarantee fees or to share in the risk. It may also involve using insurance instruments, though this remains an exception in light of limited market development to date.

- Fiscal risk management is facilitated by a legal and administrative framework clarifying relationships among different levels of government vis-à-vis the private sector.

- For fiscal risks to be properly incorporated in decision making, accurate information and suitable procedures are required in the budget and contingent liability approval process.

Source: Cebotari et al. 2009.

Practices vary across countries for contingency reserves and appropriations in the budget, and depend in part on judgments made as to the level and nature of the fiscal risks each country faces. But the maximum size of the contingency reserve is usually $5 \%$ of total expenditures, and many countries make allocations significantly below this level. The specific purposes of the contingency appropriation and the rules for using it all vary across countries.

\section{Budget Deficit Financing and Debt Sustainability}

The government is committed to keeping the fiscal deficit broadly unchanged at about 5\% of GDP, over the medium-term. It is expected that about $60 \%$ of this deficit will be financed through foreign financing, with nonconcessional external borrowing being used only to finance economically viable projects in priority sectors. The remaining $40 \%$ of the deficit will be financed through domestic financing, with an increasing proportion of such financing coming from the bond market, and less and less from credit from the CBM. With a successful arrears clearance process and with strong economic performance and growth prospects, Myanmar has been evaluated by the IMF and the World Bank as being at low risk of debt distress. 
It will be important to further enhance the Myanmar bond market. The government has been issuing 3- and 5-year Treasury bonds since 1993 and now also issues bonds with a 2-year maturity, but the market is still at a very early stage of development. The range of treasury bonds needs to be diversified and the process for issuing bonds needs to be improved. Bond trading with a focus on the secondary market needs to be supported, a corporate bond market developed, and a regulatory system for bond trading needs to be put in place. A bond settlement system and a securities depository system need to be developed. Finally, public awareness and understanding of bond trading need to be increased, along with the capacity of the concerned agencies. Enhancing the bond market along these lines will also be important in developing a yield curve for the private sector and an overall money market system. For a number of years, the government has been receiving technical assistance from the ASEAN secretariat for bond market development; and this support is expected to continue into the future.

Going forward, it will also be important that the government strengthens its public debt management capacity. As part of the government's overall public financial management reform strategy, a debt management committee will be established and the debt management system will be strengthened, with support from a range of external partners. To put in place these arrangements, Myanmar can draw on the lessons of experiences of other developing countries. These include: first, formalizing objectives for managing debt and the institutional framework for meeting those objectives; second, carefully analyzing the costs and risks of different debt strategies; third, developing domestic government securities markets and minimizing the amount of uncertainty in the market regarding government financing activities; and fourth, recognizing that sound debt management has to be part of a broader macroeconomic policy framework characterized by an appropriate exchange rate regime, a monetary policy framework that is credibly focused on the pursuit of price stability, sustainable levels of public debt, a sound external position, and a well-supervised financial system.

\section{Macroeconomic Management}

Ensuring the necessary linkages between fiscal policies and broader macroeconomic policies requires both that there is a good understanding of the differing roles and responsibilities of the three core institutions responsible (the MoFR, MNPED, and the CBM) and that there are good mechanisms for high-level policy coordination and coherence.

First, with respect to the MoFR and MNPED, the former has the responsibility for resource mobilization, but decisions on the level and allocation of expenditures will need to be made jointly by the MoFR and MNPED, with the latter being in the best position to judge the capacity of different sectoral ministries to absorb additional funds and spend them effectively. MNPED will also have an important role to play in judgments about the likely profitability of state enterprises as well as in decisions made on guarantees and PPPs - all of which are critical for understanding the level of fiscal risk the government is taking on and how best to manage that risk. So further specifying the specific roles and responsibilities of each ministry in these respects as well as putting in place the necessary coordination arrangements will be critical. Both the MoFR and MNPED also need to be given the authority to coordinate with other ministries in respect to issues of expenditure management and of public financial management more broadly.

Second, with respect to the MoFR and the CBM, many other dimensions of fiscal risk management will require that these two institutions work closely together. In addition, debt and cash management, and monetary policy need to be well-coordinated to avoid the risk of conflicting policy actions and wider economic damage. In this regard, consideration should be given to moving gradually towards a modern institutional framework in which there is a clear separation of operational roles between the Treasury 
function inside the MoFR and the CBM (Box 12), accompanied by an effective public debt management committee and other such arrangements to facilitate effective policy coordination.

\section{Box 12: Operational Roles of the Treasury and the Central Bank}

A modern institutional framework has a clear separation of roles:

- The central bank focuses on monetary policy. One result of the central bank's greater independence is that its objectives have narrowed, with the emphasis being on the control of inflation. It may still provide services to the government, such as managing the treasury single account (TSA), although transaction-banking services increasingly tend to be left to commercial banks. Where it is still a fiscal agent, the central bank's role has been more clearly that of an agent, and not as a driver of policy.

- The treasury becomes a fully-fledged function. It pools all government liquidity, takes full responsibility for debt management, and manages cash actively. There is a spectrum of practices, but effective cash management facilitates unrestricted execution of the budget. If executed well, it lowers average cash balances, thereby reducing costs, and moderates money market volatility. Ministries, departments, and agencies (MDAs) may manage their own expenditures, but the treasury manages the government's overall cash through the TSA.

- The banking sector provides banking services to the treasury and the MDAs, as required, on a transparently costed basis. This should be done through competitively tendered minimum standard service level agreements. The role of the banks depends on the degree to which government payment processing is centralized in the treasury, or dispersed to MDAs. In more decentralized payment systems, there is more room for commercial banks to provide specific services, such as the placement of short-term excess cash in a fixedterm investment.

Source: Pessoa and Williams 2012.

\section{TRANSPARENCY, ACCOUNTABILITY, AND PUBLIC FINANCIAL MANAGEMENT REFORM}

Delivering on Myanmar's fiscal objectives, including maintaining fiscal and macroeconomic stability, allocating resources in accordance with strategic priorities, and increasing the efficiency of service delivery, will require major reforms in the PFM system. Significant steps have already been taken. They include: the establishment of the Parliamentary Public Accounts and Planning and Finance Committees, the separation of regional and state budgets from the Union, the establishment of the Financial Commission and the National Planning Commission, the deconcentration of PFM policy functions from the president's office to the MoFR and MNPED, the establishment of an independent CBM, and the increased financial autonomy granted to SEEs. The government has also worked with development partners to analyze the overall public financial management system and has finalized an overall PFM strategy to address the weaknesses that have been identified. This strategy focuses on enhancing transparency and accountability, strengthening the systems for oversight and control of spending and revenue collection, institutional restructuring and clarification of roles and responsibilities, and building capacity. The challenge now is to move ahead steadily with the effective implementation of this strategy.

\section{A. Overview of Public Financial Management Reform Issues and Strategy}

During 2012, the government worked closely with the World Bank and other development partners in reviewing key dimensions of the public financial management system, including: budget credibility; comprehensiveness and transparency; policy-based budgeting; predictability and control in budget execution; accounting, recording, and reporting; and external scrutiny and audit. The review concluded that 
the system is highly constrained in delivering aggregate fiscal discipline, strategic allocation of resources and efficient services. It recommended addressing "high-priority gaps in the regulatory framework (mainly, improvements in financial regulations and minimum rules on procurement and internal audit) while commencing development of stronger overarching budget legislation (e.g., a comprehensive law covering the budgetary process) to be implemented over the medium term" (World Bank 2013, p.16).

To address these weaknesses, the government has finalized a PFM Reform Strategy (Win 2013). The overall objective of the strategy is to develop a standard of PFM that will meet regional countries' standards initially, and international, and OECD standards in the long run. The strategy focuses on three phases of PFM reform: in the first 3 to 5 years, focusing on improving control and stability in expenditure and revenue management processes while building internal capacities; in the next 5 to 8 years, focusing on developing the capacity to produce, analyze, and interpret more detailed financial management data as a basis for holding all levels of management accountable for their collection and use of public finances, and for ensuring good service delivery; and in the final 8 to 10 years, focusing on developing more sophisticated budget and management systems to improve the quality of expenditures, and achievement of public policy objectives. For the first phase of the reform, the strategy outlines both the system reforms and the institutional restructuring needed, and indicates the achievements to be expected as a result. Areas of reform for the second and third phases are also discussed in the strategy and will be addressed further below.

The development of this strategy is an important step forward and a good example of the process that ought to be followed for other important sectoral and cross-sectoral issues, whereby rigorous analytic work is followed by the development of a sound strategy for addressing the issues that have been identified. In the case of PFM, the strategy responds in large measure to the issues identified through the Public Financial Management Performance Report, recognizes the time that will be required to address those issues, and highlights the system reform requirements as well as the institutional restructuring and capacity building needed. Many of the reforms envisaged, even if successfully implemented, will have an impact only in the medium and longer term, but it is critical that these reforms are initiated now alongside the "quick wins."

\section{B. Transparency and Accountability}

The reforms undertaken to date have focused very strongly on issues related to transparency and accountability, and it appears that the government intends to continue using the transparency and accountability dimension of PFM reforms to drive the overall reform process. Of particular importance in this regard was the government's public commitment in December 2012 to the goal of joining the Extractive Industries Transparency Initiative (EITI), which requires governments to publicly disclose their revenues from natural resources such as oil, gas, and mining assets, and for companies to make parallel disclosures regarding payments (MNPED 2013). Myanmar officially became a candidate country for EITI in July 2014. Efforts are now underway to create a reporting process for revenues and payments that are currently not centrally recorded. In the absence of legal reporting requirements, this process has so far entailed trust-building with ministries and companies, and their voluntary collection and disclosure of information as well as high-level dialogue with the countries in which these companies are headquartered. The EITI process itself will not address such underlying issues in Myanmar's natural resource management, such as the original terms of contracts or the lack of clarity in land rights. In Myanmar, where the extractive industries and their historical links to the military and military business interests are points of ongoing political negotiation and violent conflict, managing expectations around EITI is crucial, as is clear communication around the EITI implementation process itself. Nonetheless, EITI is potentially an 
important example of how the process of data gathering and disclosure can significantly enhance the quality of government policies and programs, and their impact on broader development goals (Box 13).

\section{Box 13: EITI: Lessons of International Experience}

The Extractive Industries Transparency Initiative (EITI) has its roots in campaigns by Western NGOs to induce governments and the extractive industry to increase transparency and disclosure, with the goal of improving development outcomes. The EITI process is based on two components: disclosure, allowing the payment records of companies and revenue records of governments to be reconciled by an independent third party; and the establishment of multi-stakeholder groups, intended to generate civil society involvement in monitoring these figures and fostering public accountability. EITI implementation has varied across countries, and its scope and effectiveness have depended upon the buy-in of host governments. In about half of EITI countries, disclosures are made in aggregate, while in the other half, they are published company by company, resulting in greater transparency. Myanmar can choose to make such reporting mandatory.

There are two tiers of countries in EITI: candidate countries that have signed up to implement the EITI protocol and compliant countries that have fully implemented EITI. As of September 2013, there are 23 compliant countries and 16 candidate countries, along with supporting companies, institutional investors, and stakeholder NGOs and organizations, including ADB.

Successes: In Myanmar, as elsewhere, EITI could serve as an external policy anchor creating leverage for further reform, better accounting practice, or stronger regulation. In Chad, although EITI compliance was weak, EITI had an indirect beneficial effect through the enactment of new legislation and the development of monitoring bodies. EITI creates a platform for communication between the government, companies, and civil society. Indeed, Azerbaijan's government used EITI proactively as a mechanism to strengthen civil society.

Limitations: EITI itself is a voluntary process, lacking enforcement power, save potential signaling costs or reputational damage to companies or governments that fail to comply. Ultimately, EITI is only as effective as the mechanisms that allow citizens to use the disclosed information to hold governments to account. The process has also been hampered in some countries by a lack of accounting expertise. Finally, EITI focuses on a single point in the production chain (the transfer of money from the firm to the government) and ignores critical upstream stages (contracting and procurement) and downstream activities (expenditure).

Potential directions: EITI compliance may lay the groundwork and build institutional reporting infrastructure needed for domestic regulation. Firms may also be driven to comply by laws and regulations passed where they are publicly listed or registered, for example, the 2010 Dodd-Frank legislation in the US, or the April 2013 legislation passed in the European Parliament. Firms covered by these laws may now support measures to impose similar restrictions on their lessconstrained rivals. From Myanmar's perspective, EITI compliance may likewise be seen as a means to balance the significant investment of Chinese firms by drawing new investors and potentially allaying their concerns over reputational risk. At the same time, EITI at its best may serve as a platform for discussion and engagement between extractive industry players, whether new or old, and the growing number of civil society groups active in Myanmar.

NGOs = nongovernmental organizations, US = United States.

Sources: Hendrix and Noland 2015, Gillies 2010, Moran 2013, and Pyoe Pin 2013.

Of course, accountability as well as transparency is needed for high quality PFM strategiesand unfortunately, transparency alone does not automatically result in accountability (Humphreys and Weinstein 2012). To be effective, transparency initiatives must link to accountability mechanisms (Olken 2007) which, at the broadest level, can include regulatory structures, judicial oversight, or direct civil society or media pressure. Accordingly, for EITI to foster fair fiscal treatment of profits and inclusiveness through improved accountability, and for other transparency measures to have the desired impact, their processes of disclosure must be connected to accountability mechanisms. In the case of EITI, the underlying assumption is that concerned citizens will be able to use the enhanced flow of information generated by the reporting process to hold their government accountable for how it exploits its extractive resources (Pyoe Pin 2013). For this link to be completed, a free press will be critical. Myanmar's civil society will also need to grow stronger as advocates of regulatory change, and laws regulating the extractive industries will need to be passed and enforced by the judiciary. 
In sum, standardized, transparent PFM is of great importance to all stakeholders. It will help government bodies to assess the impacts of new policies and to make informed decisions in allocating resources. It will improve the confidence of the public in government and, in all likelihood, their willingness to pay taxes. It will also likely improve investor and donor confidence.

\section{Reforms of Systems, Procedures, and Rules}

In addition to focusing on issues of transparency and accountability, the PFM reform strategy focuses on reforming systems, procedures and rules for all the dimensions of PFM. These include: the planning and budgeting processes; budget execution; monitoring, accounting and reporting systems; and audit and external scrutiny.

As noted earlier, it is critical that budgeting and planning are more closely integrated than in the past, and that budgets are directly linked with the implementation of the government's priority policies and programs. The PFM strategy recognizes the importance of these issues and focuses on aligning revenue targets and expenditure ceilings with the government's overall plan; better integrating current and capital budgeting, including through the MoFR and MNPED; jointly issuing expenditure ceilings to sector ministries; and providing incentives to ministries to allocate resources more strategically. To effectively implement such changes, it will also be important to move as quickly as possible to develop and utilize a medium-term budget and expenditure framework. The links between national and local planning also need to be strengthened and the system for allocating funds to states and regions needs to be reformed (Nixon et al. 2013).

The PFM strategy recognizes the need to strengthen the budget process itself and focuses, in particular, on improvements to the budget formulation process, reducing the significance of supplementary budgets, and making the financial position of SEEs more transparent. But it is important to emphasize that issues of budget comprehensiveness go beyond issues surrounding the transparency of SEEs and revenues from natural resources.

There are a number of related concerns regarding Myanmar's budget comprehensiveness, including: (i) nonstandard reporting of some revenues and expenditures, (ii) extra-budgetary government expenditure from separate accounts within the Myanmar Economic Bank, and (iii) potential accounts held outside the Myanmar Economic Bank. In the first category, the budgets published in Myanmar's official Gazette, which inform this paper's analysis, include a line for "Other General Revenues." The sources of revenue for this budget line are not disaggregated. Second, the World Bank's Public Finance Management Performance Report identifies "Other Accounts" held by ministries and SEEs at branches of the Myanmar Economic Bank, which represent extra-budgetary expenditure and are not fully reported. In FY2011, total extra-budgetary expenditures from over 13,400 such accounts were estimated at $24 \%$ of total public expenditures (including SEE expenditures), and the revenues flowing into such accounts were estimated to be $44 \%$ of total public sector revenue (including the revenue of SEEs), much of this from the extractive sector (World Bank 2013). Most of these accounts are held by SEEs. But when SEEs (and donor programs) are excluded, spending from "Other Accounts" is still estimated to represent more than $10 \%$ of total government expenditures (World Bank 2013). Finally, Myanmar's Auditor General "has surmised that there may indeed be accounts held outside of the Myanmar Economic Bank and that some revenues generated from joint ventures, as well as from natural resources, could also be extra-budgetary" (World Bank 2013, p. 37). As these holdings are by nature unrecorded, this paper's analysis of the government's public financial management necessarily excludes them. 
Reform in these areas is needed to support the transformation of future increased revenue intake into better service delivery, which would support poverty reduction and growth. In particular, the revenue, capital, and debts of the Ministry of Defense are not disclosed in the same manner as those of other ministries (Ministry of Finance and Revenue 2013). For military spending to be shifted to more productive sectors, in line with the allocation levels of Myanmar's neighbors, the actual quantity of spending must be made clear to internal monitoring bodies and the voting public. In addition, grants from donors for projects with ministries, local governments, townships etc. also need to be properly reflected in the budget, especially because international experience has shown that including donor grant spending on-budget can improve allocation decisions and act as a curb on corruption (OECD 2010). Ministries are now required to provide such information to the MoFR but "the grant coverage in the budget is presently incomplete, partly because development partners do not always provide estimates of grant funding" (World Bank 2013, p. 44).

With respect to budget execution, the PFM strategy emphasizes: establishing stronger topdown controls; establishing a realistic first line of control around flows of funds to region and state governments; taking action to minimize use of supplementary budgets and making more timely in-year budgetary adjustments; improving tax administration; and strengthening and aligning cash and debt management to ensure fiscal sustainability and meet government financing needs at the lowest possible cost. Budget execution can also be enhanced by ensuring that the delegation of powers to spending agencies is accompanied by the introduction of clear guidelines with respect to critical dimensions of spending such as procurement and payroll management. Currently, there are no clear guidelines in place, and each spending body is left to develop its own detailed procedures and systems on matters that should be subject to government-wide standards.

Accounting, recording, and reporting is a critical dimension of PFM that may benefit from more attention in the PFM strategy. The strategy recognizes the importance of improving both the timeliness and reporting of in-year financial data using simple technology, although capacity is a concern here as elsewhere. But the focus to date has been mainly on avoiding overspending as opposed to providing information, which can be used for active in-year management and program adjustments. Provision of appropriate, accurate, and timely information is also of critical importance for risk management.

Finally, with respect to auditing and external scrutiny, both the Office of the Auditor General $(\mathrm{OAG})$ and parliament are already playing an important role. OAG has purview over all of the public sector, except the Ministry of Defense, and is responsible for setting accounting and auditing policy for the public sector. It has adopted international audit standards, reports to parliament through the president's office, and is playing an active and constructive role. The Public Accounts and Planning and Finance Committees of parliament have also been active in reviewing and rationalizing budget proposals as well as ensuring that the budget laws are published in the local press.

\section{Institutional Restructuring}

The government's PFM reform strategy recognizes that institutional restructuring must accompany reforms in systems, procedures and rules. Institutional restructuring of considerable magnitude will need to take place across ministries and from the top to the bottom of the system. The changes required in the roles and responsibilities of the core institutions responsible for macroeconomic management (the president's office, the MoFR, and MNPED) are substantial. But equally important are the changes needed within sectoral ministries and at lower levels of government. 
A deconcentration of PFM policy functions from the president's office to the MoFR and MNPED has already taken place. But some further clarification of roles and responsibilities would still be highly beneficial. This includes the role of the MoFR in supporting the Finance Commission and the role of MNPED in supporting the Planning Commission as well as the Foreign Aid Management Central and Working Committees. There are also some critical PFM issues, such as procurement and payroll management, which require macro level guidance and coordination that are not clearly assigned to any institution. In this regard, the creation in February 2013 of the "Public Service Performance Appraisal Task Force (PSPA)" chaired by a minister in the president's office provides a valuable forum both for reviewing the substance of such issues and determining where responsibility should be placed. The PSPA's responsibility for cutting red tape could also yield useful results for PFM reform-for example, in tax collection, which has been hampered by an overly complex set of schedules and tariffs which fail to create strong incentives to pay.

The MoFR has already given much thought to the major restructuring that it needs to undergo. Following the separation of the CBM from the MoFR, a new Treasury Department will be established in the MoFR to manage budget execution and reporting. The Budget Department will also be restructured in line with its new responsibilities, including by establishing a fiscal and budget policy unit, a debt management unit (to support a newly established Debt Management Committee), and a unit on inter-governmental fiscal relations, as well as an SEE monitoring function. The Internal Revenue Department is in the process of establishing a Large Taxpayers Office and taking other measures to enable it to effectively implement a new tax policy and administration plan. Other departments in the MoFR may also need to undergo some restructuring. Institutional restructuring within MNPED will also be important. The Planning Department will need to focus much more on policy planning, in addition to investment planning, and to work in a very different way with the planning departments in the sector ministries, as well as with the MoFR to ensure effective coordination between the plan and the budget, as well as between current and capital budgets. It will also need to guide the new bottom-up planning process and work closely with planning and general administration officials at local levels to ensure their work is well-integrated into the overall planning and budgeting system. The Project Appraisal and Progress Reporting Department will also need to be strengthened to undertake sound appraisal, monitoring, and evaluations of capital projects and to help effectively link the capital budget with the recurrent budget, including ensuring that there is adequate provisioning in the recurrent budget to maintain public assets. In addition, the Foreign Economic Relations Department will need to take on a very different role and set of responsibilities with respect to donor coordination than it has in the past. Restructuring along these lines is already taking place, but some further clarification of roles and responsibilities may still be needed. One important and still outstanding issue concerns responsibility for monitoring the overall implementation of the government's reform program as set out in the FESR, and including PFM reforms.

Sector ministries and lower levels of government will also need to be restructured to ensure that they are able to carry out their PFM responsibilities under the new reform strategy. Much of this restructuring will mirror the kind of restructuring going on within the MoFR and MNPED. But it will still need to be carefully thought through for each institution and in the context of government-wide guidelines.

All of this will be a particular challenge for Myanmar because of some of the legacies of the past. These include the fact that functionaries in the past were responsible to their superiors for keeping budgets, but not for spending efficiently with deliverable results (World Bank 2013). In addition, the MoFR "has historically lacked convening power over other ministries or the power to enforce fiscal policies and rules" (Pyoe Pin 2013), and a similar situation has prevailed for MNPED. 
There are parallels to the postcommunist countries of Central and Eastern Europe, where finance ministers also had relatively little influence. Studies in this region have shown that increasing the significance of the finance minister's role, for example, via responsibility for the allocation of expenditure to line ministries, can have salutary effects on fiscal performance and budget predictability (Brusis and Dimitrov 2001).

\section{E. Implementation and Capacity Building}

Developing a PFM strategy, reforming systems, procedures and rules, and restructuring institutions are in themselves challenging tasks. But even more challenging may be making sure that these strategies get implemented and achieve the results desired in terms of maintaining fiscal stability, strategically allocating financial resources, and ensuring efficient and effective delivery of public services. Indeed, a survey of PFM system characteristics and reform initiatives across 31 African countries suggests that implementation is the toughest challenge (Box 14).

\section{Box 14: Implementation of Public Financial Management Reforms in Africa}

Analysis of recent quantitative and qualitative data on public financial management (PFM) system characteristics and reform initiatives in 31 African countries highlights three themes: (i) Budgets are made better than they are executed,

(ii) Practice lags behind creation of processes and laws, and (iii) Actor concentration pays.

- The first theme relates to the observation that budget preparation processes are comparatively stronger than budget execution and oversight processes across all African countries. In PFM jargon, this is commonly presented as "upstream processes are stronger than downstream processes."

- The second theme is more nuanced, showing across all process areas that African PFM systems generally suffer from implementation deficit—laws and processes may be in place but seldom affect actual behavior. The theme reflects a new institutional differentiation between de jure and de facto reform and is shown in the words of one recent diagnostic, "Legislation and procedures have been approved......(but) implementation has not been achieved."

- The third theme offers even more specificity, suggesting that processes are stronger when narrower, concentrated sets of actors are involved in implementation. Processes are weaker where they involve multiple players, especially outside of central PFM entities like the Budget Department or Treasury.

Source: Andrews 2010.

This dynamic, with respect to implementation, reinforces the need to move quickly on capacity building across ministries and at all levels of the system. The PFM strategy recognizes both the importance and the challenge of developing sustainable capacity-including enhancing staff skills, introducing computing tools, business process reengineering, and change management-and a number of development partners are prepared to provide both financial and technical support for a comprehensive capacity building program tied to the PFM reform strategy. But international experience shows also that such capacity development strategies and programs also need very careful preparation to be effective. Particular attention needs to be paid to the role of foreign technical assistance and to making sure that it is focused on strengthening local capacity, not substituting for it. It is also clear that the impact of training programs for government officials and technical support can be greatly enhanced if they are complemented by broader organizational and civil service reforms. 


\section{REFERENCES}

Alexander, N. 2012. The Pros and Cons of Public-Private Partnerships (PPPs) as a Means to Achieve Food Security, Expanded Infrastructure Investment, and Green Growth. Washington DC: Heinrich Boell Stiftung.

Amram, M. and T. Crawford. 2011. The Upside to Fiscal Challenges: Innovative Partnerships between the Public and Private Sector. Journal of Applied Corporate Finance. 23 (3). Morgan Stanley Publication.

Andrews, M. 2010. How Far Have Public Financial Management Reforms Come in Africa? HKS Faculty Research Working Paper Series, RWP10-018, John F. Kennedy School of Government, Harvard University.

Asian Development Bank (ADB). 2013a. Key Indicators for Asia and the Pacific 2013. Manila.

-_- 2013b. Key Indicators for Asia and the Pacific 2013 Update. Manila

Auty, R. M. 1998. Resource Abundance and Economic Development: Improving the Performance of Resource-rich Countries. Research for Action 44. World Institute for Development Economics Research (UNU/WIDER). Helsinki.

Baffes, J. and A. Shah. 1993. Productivity of Public Spending, Sectoral Allocation Choices and Economic Growth. Working Paper. No. 1178. Washington, DC: World Bank.

Birdsall, N. and J. Nellis. 2003. Winners and Losers: Assessing the Distributional Impact of Privatization. World Development. 31 (10). pp. 1617-33.

Botswana Community-based Natural Resources Management Support Programme. http://www.cbnrm.bw/

Brunnschweiler, C. N. and E. H. Bulte. 2008. The Resource Curse Revisited and Revised: A Tale of Paradoxes and Red Herrings. Journal of Environmental Economics and Management. 55 (3). pp. 248-64.

Brusis, M. and V. Dimitrov. 2001. Executive Configuration and Fiscal Performance in Post-Communist Central and Eastern Europe. Journal of European Public Policy. 8 (6). pp. 888-910.

Calderon, C. and L. Serven. 2004. The Effects of Infrastructure Development on Growth and Income Distribution. Working Paper. No. 273. Central Bank of Chile.

Cebotari, A., J. M. Davis, L. Lusinyan, A. Mati, P. Mauro, M. Petrie, and R. Velloso. 2009. Fiscal Risks: Sources, Disclosure, and Management. Washington, DC: IMF.

Clements, B., S. Gupta, I. Karpowicz, and S. Tareq. 2010. Evaluating Government Employment and Compensation. IMF Technical Guidance Note. Washington, DC: IMF. 
Djankov, S. and P. Murrel. 2002. Enterprise Restructuring in Transition: A Quantitative Survey. Journal of Economic Literature. 40 (3). pp. 739-92.

European Commission. 2007. Supporting Decentralisation and Local Governance in Third Countries. January 2007. Italy.

Gillies, A. 2010. Reputational Concerns and the Emergence of Oil Sector Transparency as an International Norm. International Studies Quarterly. 54 (1). pp. 103-26.

Hendrix, C. and M. Noland. 2015. Myanmar: Cross-cutting Governance Challenges. ADB Economics Working Paper Series. No. 428. Manila.

Humphreys, M. and J. M. Weinstein. 2012. Policing Politicians: Citizen Empowerment and Political Accountability in Uganda: Preliminary Analysis. University of Columbia and Stanford University. Unpublished. http://cu-csds.org/wp-content/uploads/2009/10/ABCDE-paper.pdf

International Monetary Fund (IMF). 2009. Macro Policy Lessons for a Sound Design of Fiscal Decentralization. Washington DC.

--_. 2012. Myanmar: Article IV Consultation. IMF Country Report. No. 12/104. May. http://www.imf.org/external/pubs/ft/scr/2012/cr12104.pdf

-_-. 2013. Myanmar: 2013 Article IV Consultation and First Review under the Staff-Monitored Program. IMF Country Report. No. 13/250. August. http://www.imf.org/external/pubs/ft/scr/ 2013/cr13250.pdf

- - - 2014. Myanmar: Second Review under the Staff-Monitored Program-Staff Report and Press Release. IMF Country Report. No. 14/91. March. http://www.imf.org/external/pubs/ft/scr/ 2014/cr1491.pdf

Isham, J., M. Woolcock, L. Pritchett, and G. Busby. 2005. The Varieties of Resource Experience: Natural Resource Export Structures and the Political Economy of Economic Growth. The World Bank Economic Review. 19 (2). pp. 141-74.

Jacobs, D. F. 2009. Capital Expenditures and the Budget. IMF Technical Guidance Note. Washington, DC.

Mandl, U., A. Dierx, and F. Ilzkovitz. 2008. The Effectiveness and Efficiency of Public Spending. European Economy Economic Papers. No. 301. Brussels: European Commission.

McLure, C. E. and J. Martinez-Vazquez. 2000. The Assignment of Revenues and Expenditures in Intergovernmental Fiscal Relations. Paper prepared for the core course on Intergovernmental Relations and Local Financial Management, World Bank Institute, Washington, DC: World Bank.

Ministry of Energy. 2014. Data on oil and gas reserves provided to authors. 
Ministry of Finance and Revenue. 2013. Public Financial Management (PFM) Reform Strategy. Nay Pyi Taw.

Ministry of Information. 2008. Constitution of the Republic of the Union of Myanmar. Nay Pyi Taw.

Ministry of National Planning and Economic Development (MNPED). 2013. Framework for Economic and Social Reforms: Policy Priorities for 2012-2015 towards the Long-Term Goals of the National Comprehensive Development Plan. Nay Pyi Taw.

- - 2014. Selected Monthly Economic Indicators.

Moran, T. H. 2013. Reform EITI to Require Compliant Countries to Publish Disaggregated Company-byCompany Revenue Payments. Washington, DC: Center for Global Development.

Nixon, H., C. Joelene, K. P. C. Saw, T. A. Lynn, M. Arnold. 2013. State and Region Governments in Myanmar. Myanmar Development Resource Institute-Centre for Economic and Social Development and the Asia Foundation.

Olken, B. 2007. Monitoring Corruption: Evidence from a Field Experiment in Indonesia. Journal of Political Economy. 115 (2). pp. 200-49.

Organisation for Economic Co-operation and Development (OECD)-Development Assistance Committee (DAC). http://www.oecd.org/dac/stats/ (accessed July 2014).

- - - 2010. What Are the Benefits of Using Country Systems? Policy Brief 3: Sector Audiences. http://www.oecd.org/development/effectiveness/48780926.pdf

Pessoa, M. and M. Williams. 2012. Government Cash Management: Relationship between the Treasury and the Central Bank. IMF Technical Notes and Manuals. Washington, DC.

Public-Private Partnership in Infrastructure Resource Center for Contracts, Laws and Regulations (PPPIRC). http://ppp.worldbank.org/public-private-partnership/about-pppirc

Pyoe Pin. 2013. The Political Economy of Myanmar's EITI Process. Unpublished.

Rieffel, L. and J. W. Fox. 2013. Too Much, Too Soon? The Dilemma of Foreign Aid to Myanmar/Burma. Nathan Associates. Arlington.

Shendy, R., Z. Kaplan, and P. Mousley. 2011. Towards Better Infrastructure: Conditions, Constraints, and Opportunities in Financing Public-Private Partnerships in Select African Countries. Washington, DC: World Bank.

Shirley, M. M. 1992. The What, Why, and How of Privatization: A World Bank Perspective. Fordham Law Review. 60 (6).

Tandon, A., C. J. L. Murray, J. A. Lauer, and D. B. Evans. 2001. Measuring Overall Health System Performance for 191 Countries. WHO GPE Discussion Paper Series. No. 30. http://www.who.int/healthinfo/paper30.pdf 
Tanzi, V. and H. H. Zee. 2000. Tax Policy for Emerging Markets: Developing Economies. IMF Working Paper No. 35. Washington, DC.

The New Light of Myanmar. 2013. National reform heading committee led by the President has been formed separately to direct efforts on reform programme. Nay Pyi Taw. 10 August. http://www.burmalibrary.org/docs15/NLM-2013-08-10-red.pdf

Turnell, S. 2011. Fundamentals of Myanmar's Macroeconomy: A Political Economy Perspective. Asian Economic Policy Review. 6 (1). pp. 136-53.

Union Government of Myanmar. 2011. Myanmar Union Budget Law (2011-2012). Nay Pyi Taw.

-_- 2012. Myanmar Supplementary Union Budget Law (2012-2013). Nay Pyi Taw.

- - 2013. Myanmar Union Budget Law (2013-2014). Nay Pyi Taw.

-_- 2014. Myanmar Union Budget Law (2014-2015). Nay Pyi Taw.

United Nations Development Programme (UNDP). 2005. Primer: Fiscal Decentralization and Poverty Reduction. New York.

Van der Ploeg, F. and A. J. Venables. 2013. Natural Resource Wealth: The Challenge of Managing a Windfall. OxCarre Research Paper. No. 75. Oxford: University of Oxford.

Wennmann, A. 2012. Sharing Natural Resource Wealth during War-to-Peace Transitions. In P. Lujala P. and S. A. Rustad, eds. High-Value Natural Resources and Peacebuilding. London: Earthscan.

Win, M. M. 2013. Draft PFM Reform Strategy for Myanmar. A powerpoint presentation by the Director General, Budget Department, Ministry of Finance and Revenue. Nay Pyi Taw.

World Bank. World Development Indicators. http://data.worldbank.org/data-catalog/ worlddevelopmentindicators

-_- 2011. Wage Bill and Pay Compression Summary Note. Washington, DC.

-_- 2012. World Bank East Asia and Pacific Economic Update 2012, Volume 1: Capturing New Sources of Growth. Washington, DC: World Bank.

- - - 2013. Public Financial Management Performance Report: Republic of the Union of Myanmar. Washington, DC: World Bank. 


\section{Fiscal Management in Myanmar}

Taking off from a system characterized by weak fiscal management, the present government restored a measure of fiscal discipline, reoriented fiscal priorities, and established a clear set of fiscal objectives in the Framework for Economic and Social Reforms. The Government of Myanmar now has to prioritize how best to implement these fiscal objectives while strengthening long-run fiscal discipline. This paper provides a broad range of recommendations on how this can be achieved, using analysis of Myanmar's present and past fiscal situation alongside insights provided by the experience of other countries.

\section{About the Asian Development Bank}

ADB's vision is an Asia and Pacific region free of poverty. Its mission is to help its developing member countries reduce poverty and improve the quality of life of their people. Despite the region's many successes, it remains home to the majority of the world's poor. $A D B$ is committed to reducing poverty through inclusive economic growth, environmentally sustainable growth, and regional integration.

Based in Manila, ADB is owned by 67 members, including 48 from the region. Its main instruments for helping its developing member countries are policy dialogue, loans, equity investments, guarantees, grants, and technical assistance. 